\title{
Modern Türk Düşüncesinde Mantık Çalışmaları
}

\author{
İsmail KÖZ \\ Dr., Ankara Üniversitesi İlâhiyat Fakültesi \\ e-mail:koz@divinity.ankara.edu.tr
}

Studies on Logic in Modern Turkish Thought. Logical studies in modern Turkish thought can be divided into three groups: 1. Traditional categorical logic which depends upon Aristotelian logic and is restricted to Farabi's and Avicenna's logical investigations. Logic is not a formal system in the İslamic thought, and therefore, it had been regarded as an instrument; yet Avicenna's logical attempts are accepted as a formal system. 2. Logical studies in the second group consist of traditional categorical logic and modern logic. During this attitude methodology had becomea very important subject in logical investigations. This approach influenced logical studies in Turkish thought. In Western philosophy, 1600 A.D there had been a resurgence of interest in logical and mathematical inquiry; Turkish thought however was unaware of the movements took place in Western philosophy towards the end of the Eighteenth Century. 3. In the third group, logical studies were restricted only to modern logical problems. Therefore traditional logic was given very little place in this approach, but mathematical logic, symbolic logic, transcendental logic and formal logic were the main subjects.

Key Words: Traditional Categorical Logic, Modern Logic, Symbolic Logic, Methodology, Instrument, Formal System. 
Türkiye'de mantık çalışmalarını genel olarak geleneğe bağlı mantık çalışmaları ve modern mantık araştırmaları şeklinde iki ana grupta toplayabiliriz. Geleneğe bağlı mantık çalışmalarını da yeni mantık cereyanları içerisinde ele alıyoruz. Çünkü, Tanzimattan sonra, Batıda meydana gelen modern mantık çalışmalarının Türk fikir hayatında görülmesine paralel olarak geleneksel mantık da yeni bir uyanış dönemine girmiştir. Batıda klasik mantığın yetersizliği gündeme gelince yeni mantık arayışları neticesinde modern mantık şekillenmeye başlarken, Türk fikir hayatında da bu modern mantığın karşısında geleneksel mantığın geliştiğini ve yaygınlık kazandığını görüyoruz. Bu husus Türk mantık cereyanlarının karakteristik bir yönüdür.

Tanzimatın ilk dönemlerinde bir millileşme hareketi ortaya çıkarak, medrese sınırları içerisinde kalan geleneksel İslâm düşüncesi medrese dışına da yayılmaya başlamıştı. Bunun sonucunda İslâm mantık bilgisi Türkçeleşip sadeleşmiş; henüz pek cılız olan batılı fikirlerin karşısında, çok açık ve sistemli olması nedeniyle önemli bir üstünlük kazanmıştır. Bunda Arapça metin ve şerhlerin tercümelerinin basımevlerinde daha kolay bastırılmasının etkisi büyük olmuştur. Eski mantığa rağbetin scbepleri arasında batıcılık hareketine karşı tepkiyi de zikredebiliriz.' Bir taraftan batılılaşma ve çağdaşlaşma düşüncesi kuvvetlenirken diğer tarafta geleneksel İslâm düşüncesine bağ $l_{1} l_{1 k}$ fikri yerleşmekteydi. Yeni bilimlerin geleneksel düşünceye zarar vermemesi için İslâm düşüncesinde önemli bir yeri olan sûri (formel) mantığın yeni açılan okullarda okutulmasına ve bu konuyla ilgili kitapların tercüme ve telifine çalışıliyordu. ${ }^{2}$

Yazılan mantık kitapları Arapça olduğu için 19. Asrın ikinci yarısına kadar Osmanlı medreselerinde mantık Arapça okutulmaktaydı. Tanzimattan sonra medreselerin yanında yeni mektepler açılınca, Türkçe mantık kitapları yazılarak ve bazı Arapça kitaplar da Türkçe'ye çevrilerek buralarda mantık dersleri Türkçe okutulmaya başlanmıştır. ${ }^{3}$

Türk mantık cereyanları üzerinde araştırma yapanlar bu dönemi geleneğe uygun eskinin devamı, uzlaşmacı mantık araştırmaları ve modern mantık çalışmaları şeklinde üç kategoride ele almaktadırlar. ${ }^{4}$

Geleneğe uygun mantık çalışmalarından kasıt, Farabî (870-950) ve İbn Sinâ'(980-1037) nın Aristo (M.Ö.384-322) mantığına dayanarak oluşturduğu İslâm mantık geleneği çizgisindeki çalı̧̧malardır.

"Gerek İslâm kültür dünyasında ve gerekse Batıda asırlar boyunca mantık konusunda yapılan çalışmalar, Aristoteles'in fikirleri etrafında gelişmiştir.

' Bkz. Ülken, Hilmi Ziya, Türkiye'de Çăgdaş Düşünce Tarihi, 2. Bsk., İstanbul, 1979. s 68

2 Uiken, Hilmi Ziya, "Tanzimattan Sonra Fikir Harekctleri”, Tanzimat (Kitabı içinde) Maarif Vekaleti. Istanbul 1940 s. 13

${ }^{3}$ Oner, Necati, "Türkiye'de Mantık Çalışmaları", Felsefe Dünyası, say. 6. Aralık, 1992, s. 3

4 Bkz. Ulken, Hilmi Ziya, "Tanzimattan Sonra Mantık Harcketleri”. Edebivat Fak. Tarih Mecmuası, sayı: 1, İstanbul, Mayıs- 1934, s. 37-51; Öner, Necati, Tanzimattan Sonra Türkiye'de Ilim ve Mantık Anlaylşı, A.Ü.I.F.Y Yay., Ankara, 1967, s. 12, 50, 61 
Aristoteles Organon'u altı kitaptan oluşmaktaydı. Daha sonra Stoacılar ve Yeni Platoncular konu üzerinde çalışmalarını sürdürmüşler; bu dönemde Aristoteles'in iki eseri Retorika ve Poetika'da Organon külliyatından sayılmış, ayrıca yeni Platoncu Porphyrios (M.S. 232304)'un Isagoji'si de Aristoteles Organon'unun başına eklenmiştir. Böylece önce İskenderiyeli Şarihlerin, sonraları Hristiyan Süryanilerin elinde şerh ve tercume edilmek suretiyle asırlarca incelenmiştir. İslam Dünyası'na geçmeden önce Süryanilerde Mantık külliyatını dokuz kitap olarak görmekteyiz: Eisagoge, Kategoriler, Peri-Ermeneias, IAnalitikler, II Analitikler, Topika (Dialektika), Sofistika, Retorika, Poetika. Bu tespit genelde İslam özelde Osmanlı kültür dünyasında mantığın şekillenmesi bakımından oldukça önemlidir. Zira Osmanlı dünyasında mantığı, İslam dünyasında mantıktan soyutlamak mümkün değildir."s

Müslümanlar, miladi VII. Asrın ortalarında fethettikleri Suriye ve civarında Aristoteles mantığının oldukça inkişaf etmiş olduğu şekliyle karşılaşmışlar ve İslam dünyasında ilk mantık metinleri de yine bu Süryanice metinlerden Arapça'ya yapılan çevirilerle oluşturulmuştur. Abbasiler devrinde ve bilhassa el-Mansûr (754-755) ve el-Me'mun (814-833) zamanlarında gerçekleştirilen yoğun tercüme faaliyetleri sonucunda, Aristoteles'in bütün mantık külliyatını ve Porphyrios'un Isagoji'sini bazı şerhleriyle birlikte Miladi IX. Asırda Arap dilinde görmek mümkün olmuştur. 6

Hiç kuşkusuz bu tercüme faaliyetleri büyük bir telif faaliyetini de hazırlamıştır. Kindi, Farabî, İbn Sinâ, İbn Rüşd (M.1126-1 198), Fahred-dîni Râzi (M.1149-1209), Seyyid Şerif Cürcanî (M.1340-1413), v.b gibi düşünürler mantık ilmini, spekülasyonlarının başlangıcı; sistemlerinin temeli saymışlardır.' Böylece İslâm dünyasında Grek medeniyctinin tesiri ile rasyonel bir ilim anlayışı doğmuştur.

Tercümeler devrini kapatıp, yetkin, tam, kendi felsefe sistemiyle tutarlı ve zengin muhtevalı eserler ortaya koyarak mantığa İslam kültürünün hüviyetini kazandıran ilk filozof Uzlukoğlu Farabî olmuştur. İslam kültür dünyasında mantıkçılar arasında üstün bir şöhrete sahip olan bir başka Türk asıllı filozof İbn Sinâ ile adeta bir İslam mantık geleneği kurulmuştur. Bu gelenek her ne kadar Stoacı ve Yeni Eflatuncu süzgeçten geçen Aristoteles (M.Ö. 384-322) ve Porphyrios'un eserlerine dayanmış olsa da, bu İslam kültür çevresinde $X$. Yüzyılda ortaya koyulan bu çabaların değerini azaltmaz. Çünkü kavramın incelenmesi ve çeşitli yönleriyle araştırılmasından ibaret beş tümelin tanımı, adsal tanımlar, modalite ve modal önermeler ve nihayet kıyasın formu ve maddesi açısından yapılan araştırmalar, Arap dilinin özellikleriyle de birleşince, genel mantık tarihi

\footnotetext{
SBingöl, Abdulkuddüs, "Osmanlı Dünyası'nda Mantık Bilimi ve Eğitimi”, Felsefe Dünyast, say1: 29, T'cmmuz, 1999-1, s. 12

${ }^{6}$ Bingöl, Abdulkuddüs, A. g. m., ss. 12-13

${ }^{7}$ Porphyrios, Ísagoji. Çev. Hamdi Ragıp Atademir, Konya, 1948, s. 15
} 
içerisinde kendine özgü nitelikleriyle bir İslam mantığının veya bir İslam mantık tarihinin oluşumunu da sağlamıştır. ${ }^{8}$

"Mantık Gazzali (1058-1111) ile fiilen Usul İlimlerinde (Dini ilimler metodolojisinde) önemli bir rol oynamıştır. Usülcüler mantığın özellikle Kavram Tahlili, Delâlet ve Ta'rif (Tanım) konularından son derece yararlanmışlardır. Uygulama alanlarında yararlı olması açısından mantığın bu konuları gerektiğinden fazla incelenmiş ve mantık yalnız felsefecilerin uğraştı̆̆ 1 bir alan olmaktan çıkmıştır. Dinî ilimlerde, özellikle kelam tartışmalarında İslam bilginlerinin metotlarının esasını mantığın temel kuralları oluşturmaktaydı. Bununla beraber, Aristoteles' in cevher tanımının İslam akidesiyle telifini imkansız gören kelamcıların etkisiyle, mantık kitaplanndan Kategoriler bölümü çıkarılmıştır."

Osmanlı öncesi dönemin son halkalarında bulunan al-Ebheri (öl.1264)'nin Ísagoji'si ve al-Semerkandi (öl.1302)'nin Kıstas'ı tertip va anlatım yönünden orijinaldir. Her ikisi için de sahifelerce şerhler ve haşiyeler yazılmıştır. Bu eserlerde artık ilk dönem eserlerde gördüğümüz mantık konularının dokuz kitap veya dokuz bölüm halinde ele alınıp incelenmesi gibi bir tertip sözkonusu olmadığı gibi, konular açıklanırken hem daha öncekilere atıflarda bulunulmakta hem de tam bir yetkinlikle tartışılmaktadır. Artık mantık konuları iki temel başlık altında toplanarak, Mantık "Tasavvurat" ve "Tasdikat" bölümlerine ayrılmakta ve bunlar da kendi içlerinde alt başlıklara bölünerek işlenmektedir. İşte Osmanlı dünyasında mantık biliminin muhtevasını diğer birçok alanda olduğu gibi İslam kültür mirasının ortak malı olarak Osmanlılara intikal eden bütün bu gelişmeler oluşturmaktadır. Bu muhteva XIX. Yüzyılın son çeyreğine kadar özde hemen hiçbir değişiklik göstermeden hakim anlayış olacaktır. ${ }^{10}$

Ancak şu da var ki, daha sonra gelen İslâm mantıkçıları, Farabi ve İbn Sina geleneğini takip ettikleri halde yazdıkları mantık kitaplarında bazı değişiklikler yaptılar. Tanım bahsini burhan kısmından çıkarıp "Beş Tümel"e eklediler. Kategoriler kısmını ise mantık'ın konuları arasından çıkardılar. Burhan, cedel, hitabet, şiir ve safsatadan ibaret olan beş kitabı da ihmal edip kısaca değinerek geçiştirmişlerdir. Öner'e göre aslında bütün bu değişikliklerin temelinde İbn Sina'nın görüşleri olduğu söylenebilir." Mantıkçı Yaren ise bu konuda şunları söylemektedir:

"İbn Sina en-Necat adlı kitabında kategorileri tanım teorisi ile birlikte ele almıştır; böyle yapılabileceğini şifa adlı kitabında da söylemiştir. Işarat'ta ise Kategorilere yer vermemiştir. Onun bu tutumu İslam dünyasındaki mantık çalışmaları üzerinde etkili olmuş bunun sonucu olarak mantık kitaplarının tamamına yakınında kategoriler bahsi yer almamıştır."12

\footnotetext{
${ }^{8}$ Bingöl, Abdulkuddüs, A. g. m., s. 13

'Bingöl, Abdulkuddüs, A. g. m., s. 14

${ }^{10}$ Bingöl, Abdulkuddüs, A.g. m., s. 14

"Öner, Necati, Tanzimattan Sonra Türkiye'de Ilim ve Mantık Anlayısı, s. 9

12 Yaren Tahir, Ibn Sina Mantığına Giriş, Ankara, 1996, s.19
} 
İbn Sina'ya göre mantık ister felsefenin bir kısmı sayılsın, isterse felsefeden bağımsız olsun daima bir alettir. ${ }^{13}$ Gerçekte İ Islâm düşüncesinde mantığın bir sanat mı, yoksa ilim mi olduğu tartışması önemli bir yer tutar. Afrodisiaslı İskender'den Gelenbevi'(1730-1791) ye kadar bütün İslâm mantıkçıları için müş̧terek ve umumî mesele mantığın sanat $\mathrm{m}$, ilim mi olduğu konusu idi. ${ }^{\stackrel{4}{4}}$ Aristo'nun bilimler sinıflamasında mantığa yer vermediği söylenmektedir. Onun, mantığı bilim olarak değil de, zaruri ve ispatçı bilimin aleti olarak gördüğü fikri yaygındır. İslâm düşünürlerinde de bu fikrin ağır bastığı belirtilmektedir. ${ }^{15}$

"İslâm mantık telakkisi mantığın bir alet olduğu yönünde ağır bastığı için İslâm aleminde mantığın suriliği fikri yenidir. Suri mantık tabiri olmadığı gibi bu telakkiye de yanaşmamışlardır. İlk İslâm filozofları suri mantık telakkisine karşıydılar. Mantı̆̆ diğer ilimlerden ayırmak şöyle dursun, bilakis ona fizik ve matafizik meseleleri raptediyorlards". ${ }^{6}$

Ancak şunu da ifade etmelidir ki, Farabi mantığa, bilimler sınıflamasında ayrı bir yer ayırmaktadır. Çünkü o, mantığı açıkça ayrı bir bilim dalı olarak kabul etmiştir. ${ }^{17} \mathrm{Bu}$ tutumunda da orijinallik arzeder.

İbn Sina'nın, Porphrios ağacı anlayışını tenkit etmiş ${ }^{18}$ olması mantıkta formalizme kapı açmıştır. Ancak İslâm skolastiğinin yıkılış devrinde mantık suri bir karakter almıştır. ${ }^{19}$ İbn Sina'ya göre düşüncenin terimlerle bir ilgisi yoktur. Eğer düşünceyi terimlerden başka bir araçla ifade mümkün olsaydı, pekala onlardan vazgeçebilirdik. Mantığı her türlü kelâmı araçlardan kurtarmak istcyen ve ondan daha basit ve mücerret bir vasıta araştıran İbn Sina bu vasıtayı bulamamışsa da onun imkanını hissetmiştir. Bunun için modern lojistiği sezmiştir, denebilir. ${ }^{20}$

Ülken'e göre, İbn Sina Leibniz' (1646-1716) den evvel dilden başka bir vasıta ile bir nevi "Caracteristic Generale" yapma lüzum ve ihtiyacını ileri

${ }_{13}^{13}$ Ülken, Hilmi Ziya, Mantık Tarihi, İstanbul, 1942, s. 82

${ }_{15}^{14}$ Ulken, Hilmi Ziya, A. g. c. , s. 9

15 Porphyrios, Isagoji, s. 9

${ }^{16}$ Ülken. Hilmi Ziya, A. g. c., s. 83

${ }^{17}$ Farabi. Ihsaul Ulum. Çev. Ahmet Ateş, 3. Bsk., İstanbul. 1990. ss. 48-49; Krş Bayraktar, Mehmet, Islam Felsefesine Giris, Ankara. 1997, s. 122

${ }_{18}$ Yaren Tahir, Ibn Sina Mantığma Giris, s.12-13

${ }^{19}$ Ülken, Hilmi Ziya. A. g.c. s. 83

${ }^{20}$ Ulken. Hilmi Ziya, A. g. e. s. 84

Bu terim "Universal Caracteristic" diye de ifade edilir. Leibniz yeni bir mantık bilimi kurarken büyük ölçüde matematiği model alıp mantık ile matematiği uzlaş̧ırmağa hatta mantığı matematikselleştirmeye çalışmıştır. Ona göre mantık ve kıyas teorisi evrensel bir matematiktir. Bu yüzden Leibniz mantığı matematik metodun bir gencllemesi olarak düşünmüşür. Denilebilir ki, Lcibniz matematiği mantığın özcl bir şekli olarak görür: Aristo mantığ yoluna ilk Leibniz gitmiştir. Mantık, çıarsamayı önermelerin muhtevalarından tamamen bağgımsız kılmalıdır. Matcmatik, mazhar olduğu büyük ilerlemeyi böylc bir bağımsızlığa borçludur. Çünkü mekanik hesap, akılyürütmcyi son derece kolaylaştırmakta ve muhtevalı düşünüşü her zaman tehdideden yanılmalardan korumaktadır. Ohalde başarılması gereken iş mantığı öyle kurmaktır ki, matematik gibi olsun; yani çıkarım kuralları birer hesap (calcul) kuralı olsun. Bunun içindir ki, kurallar o tarzda verilmelidir $\mathrm{ki}$, işarctler kullanılırken manalarının muhtevaları üzerinde düsünmeğe hiç lüzum kalmasın. Böyle bir hesap da ancak günlük dil yerinc yapma bir dil koymakla, bir başka deyimle. bir semboller sistemi kurmakla olur. Bu sembollerle 
sürmüş, fakat yapamamıştır. Günlük dilden memnun olmadığı için düşüncelerimizi daha iyi ve vasıtasız ifade edecek bir sistem aramış, ancak geleneğe bağh kalmak üzere Aristo ve Eflatun (M.Ö. 427-347) ile beraber imajsız tefekkür olmadığı ve düşünmek deruni bir konuşmadır, neticesine varmıştır. Bununla beraber alfabe harfleri vasıtasıyla Bertrand Russell (1872-1970) ve Couturat'ın mantıkî cebrine benzeyen felsefi bir cebir levhası teşkil ederek bütün önerme şekillerini kelimesiz olarak yalnız harflerle göstermiştir. Fakat bu onun matematik ile mantık arasında irtibat kurarak bu "Caracteristic"i bu günkü neticelerine kadar götürmesine hizmet edememiştir. İbn Sina'nın bu çalışmalarını sembolik mantık çalışmaları olarak görebiliriz. ${ }^{21}$

İbn Sina'dan sonra İslâm mantığı eski metinler üzerinde yapılan şerhler, haşiyeler ve takrirlerden teşekkül ediyordu. Şunu da belirtmelidir ki, bugün bilinen eserlerin sayısı zamandaş olarak Batıdakilerden çok fazla olsa da, asrının en büyük mantıkçısı olarak kabul edilen Gelenbevi İsmail Efendi bir tarafa birakılacak olursa XV. Yüzyıldan itibaren Tanzimata (1839) kadar Osmanlı dünyasında münferit şerh ve haşiyelerin dışında orijinal telifler görmek pek mümkün olmadı̆̆ 1 gibi, bu dönemde XVI. Yüzyıldan itibaren hızla gelişen batıdaki bilim ve mantık anlayışından izlere rastlamak da mümkün olmamıştır. Esasen XVIII. Yüzyıl Türk aydını, mantık konularında ne biliyorsa, XIII. Yüzyıl Türk aydını da aynı şeyi bilmektedir. ${ }^{22}$ Batıda mantık, önce metodoloji alanında sonra da "lojistik"" adı altında formel mantıkta büyük bir gelişme göstermiştir.Batıda formel mantık alanında görülen bu önemli gelişmenin temelinde Yeniçağ'dan itibaren matematik biliminin ve matematik düşüncenin hızla gelişmesinin etkisini görebiliriz.

Avrupa'da Renaissance'den sonra pozitif bilimlerde baş gösteren gelişmeler o çağa kadar hakim olan Aristo mantı̆̆ının yetersizliği fikrini doğurmuş ve bu mantığı genişletme amacıyla çalı̧̧malar başlamıştır. Bir yandan bilimlerin metotları üzerinde incelemeler devam ederken, XIX. Asrın ortalarından itibaren de İngiliz mantıkçıları matematiği esas alarak mantık problemlerini yeni bir yolda işlemeğe başlamışlardı. Fikir hayatımız uzun

işlemlerde bulunurken önermelerin muhtevalan üzerinde asla düşünülmemelidir. "Karakteristik", işte böyle böyle bir sistemdir. Leibniz ona "Caractéristique Universelle" der. Leibniz, Metafizik Üzerine Konuşma, Çcv. Nusret Hizır, İstanbul, 1949, ss. (Önsöz) XIII-XIV; Nusret Hızır, "Yeni Mantığın Öncüsü Leibniz", A.U.D.T.C.F. Dergisi, c. III. sayı: 4. 1945, s. 433-440; Vehbi Eralp, Matemarik, Fizik ve Kimvada Metod. İ tanbul. 1947, s. 21

${ }^{21}$ Ülken, Hilmi Ziya, Mantık Tarihi, s. 85

${ }_{22}$ Bingöl, Abdulkuddüs. "Osmanlı Dünyası'nda Mantık Bilimi ve Eğitimi", s. 15

- Mantık, düşünüşün sadece işleme yollarının, işleme şckillerinin bilimidir. Düşünüşün içerikten słyrılmış olarak işlemesi simgelerle gösterilebileceğine göre, mantık da tıpkı matematik gibi simgeler yardımı ile kurulacaktır. Matematiğe bu benzetme bir rastlant değildir. Cünkü matematik de $a, b, c$, ve bunun gibi salt şekiller, salt simgelerle uğraşır. Matematik de formel yani içi boş bir kahıplar sistemi olduğundan dolayı hesap ve işlem olarak gelişmiştir. Demek $\mathrm{kj}$, mantık hesap ve işlem olarak kurulacak, düşüncenin iç yapısı ile ilgili her türlü oge ondan uzak tutulacak ve matematikte olduğu gibi imli ve simgeli bir işlemler bütünü halini alacaktır. Iş̧c yeni mantığın gelişmesini yöneten ilke budur. Simdi simgesel mantık (logique symbolique), matematik mantık yada lojistik adı verilen bu mantıktır. Nusret Hizır. Felsefe Yazıları 2. Bsk., Istanbul, 1981, ss. 225-226 
Zaman mantığın bu gelişmesinden habersiz kalmış, Aristo mantığının dışına çıkamamıştır. ${ }^{23}$

Yeniçağ'da pozitif bilimler ve matematikte görülen gelişmelerle birlikte yeni mantık çalışmaları ortaya çıkmış, klasik mantığın yanında yeni mantık cereyanları gündeme gelmiştir.

Bilindiği gibi Francis Bacon (1561-1626), Yeni Organon adlı kitabında yeni mantık hareketinin önemli bir aşamasını gerçekleştirmiştir. Bu çalışmasıyla Aristo'nun kıyasına karşı tümevarım metodunu savunmuştur. Fakat modern felsefedeki mantık cereyanlarının hareket noktasını bulamamıştı. Çünkü, kıyasla birlikte bütün dedüksiyon reddedilmiş; tümevarım sağlam bir temele bağlanamayarak, yalnızca tabiatın incelenmesine bağlı bir süreç halinde bırakılmıştır. Mantığa yeni bir yön kazandıran, bilimin akılyürütme şekillerini ortaya koyan ve bu itibarla Aristo'ya karşı yeni mantığın asıl kurucusu olan René Descartes (15961650)' tır. ${ }^{24}$

Batıda bu gelişmeler olurken İslâm dünyasında da Aristo mantığına dayalı geleneksel mantık çalışmaları devam ediyordu. Osmanlı diyebileceğimiz 13-19. Yüzyıllar arasındaki Türk kültürü 16. Yüzyıldan itibaren batı kültürünün ilim ve felsefede kazandığı büyük ilerlemeleri takip edememiş, İslâm medeniyetinin 8 ila 11. Yüzylllardaki müsbet ilim seviyesini koruyamamıştır. İlim alanındaki kapalılık felsefede de kapalılığı doğurmuş, felsefe skolastik içine girmiş, ilim felsefesi eğilimi zayıflamış, tabiat felsefesi ve Aristoculuğa karşı şiddetli hücumlar ortaya çıkmış; bunun yanında da formel mantıkta kılı kırk yararcasına pek çok eser yazılmıştır. ${ }^{25}$ Bütün bunlara sebep olarak eski ilim anlayışının tatbik edildiği medreselerde en fazla dini bilgilere yer verilmesini zikredebiliriz. Dolayısıyla çalışmaların ağırlık merkezini dini bilgiler teşkil etmiştir. Medreselerdeki bu zihniyet rasyonel düşünceyi ikinci plana atmış, müspet bilimler sahasında herhangi bir ilmî gelişme olmadığı gibi, batı bilimindeki gelişmeler de takip edilememiştir. ${ }^{26}$

Netice itibariyle Tanzimat öncesi Türk düşünce hayatına baktığımızda bilim, felsefe ve mantık alanında Batıda meydana gelen gelişmelerden habersiz; kendi içine kapanmı̧, bilim ve felsefe alanında yeni bir şeyler üretemeyen, sürekli eskinin devamı niteliğinde ve dini bilgilere ağırlık veren çalışmalarla ve skolastik felsefeyle meşgul olduğunu görüyoruz.

Türk düşüncesi, yeniçağ felsefesinde Batı'da mantık alanında ortaya atılan yeni fikirlerden ancak Tanzimattan sonra haberdar olmuştur. Tanzimatın ilk devirlerinde yine skolastik mantık eserleri hakimdi. ${ }^{27}$

\footnotetext{
${ }^{23}$ Öner, Necati, "Türkiye'dc Yeni Mantık Cereyanlarının Illk Habercisi: Ali Sedat", A. Ü. i. Fak. Dergisi. C. VI, sayı: I-IV, 1959, s. 61

${ }^{24}$ Ülken, Hilmi Ziya, "Türkiye'de Tanzimattan Sonraki Mantık Harcketlen", s. 44

¿ Ülken, Hilmi Ziya. Türkive' de Cağdas Düsünce Tarihi, s. 41

${ }^{20}$ Korlaelçi, Murtaza. Pozitivizmin Türkiye ye Girişi vé Ilk Etkileri, Insan yay., İstanbul, 1986, s. 185

${ }^{27}$ Ulken. Hilmi Ziya, "Tanzimattan Sonra Mantık Harcketleri", s. 37; Öner. Necati,

"Tanzimattan Sonra Türkiye'de Illim ve Mantık Anlayışı". s. 11
} 
Tanzimatla başlayan yeni mantık hareketleri, didaktik ve sathi kalmış, maalesef kuvvetle yerleşememiştir. İlim ve mantık anlayışının gelişmelerine karşı duyulan büyük ihtiyaç bazı tercüme ve telif escrlerle bizde de vakit vakit kendini hissettirmiş olmasına rağmen ne klasik mantık anlayışını, ne de yeni anlayışları benimseyen bir fikir ve kürsü geleneği oluşturulamamıştır. ${ }^{28}$

Tanzimat devrinin bariz karakteri düşüncede ve hayatta ikiliktir. Eski ve yeni aynı devirde karşı karşıya yer almaktadır. Bu ikilik başlıca yeni kurulan ilim ve eğitim kurumları ile eskileri arasında açıkça görülürr. ${ }^{29}$

"Yakın senelere kadar suri mantığın mukavemetleri, felsefe cereyanlarının zaifliği, garp ilminin yalnızca teknik gayelerle memlekete girmiş olması gibi sebepler yeni mantık cereyanlarının yerleşmesini geciktirmiştir." 30

Asıl batı medeniyetinin temeli olan zihniyeti, felsefesi, araştırma metotları bilinmediği için Tanzimatın getirdiği batılı fikirler daima yüzeysel kaliyordu.

Osmanlılarda bilim anlayışı imparatorluğu ıslah gayesiyle açılan yeni eğitim kurumları ile yenileşmeye başlar. Bu yenilik Batıda gelişen müspet bilimlere karşı duyulan ilgidir. ${ }^{31}$

Batı biliminde görülen gelişmenin temelinde yatan en önemli gerçek Yeniçağda ortaya çıkan modern matematik çalışmalarıdır. Giordano Bruno (1548-1600)'nun derin felsefî spekülasyonu, Galileo Galilei(1564-1642) ve Descartes'in matematik akılyürütmeye dayanan sağlam sezgiciliği Türk toplumunca bilinmiyordu. ${ }^{32}$

Osmanlı medreselerinde erken dönemde matematik öğrenimi gelişmeye başlamıştı. İlk ünlü matematikçi Kadızade Rumi Türkistan'a gitmiş, hayatını Uluğ Bey'in kurduğu medrese ve rasathanede geçirmişti. Kadızade'nin öğrencisi Ali Kuşçu ile Türkistan'dan Türkiye'ye gelmiş ve eserlerini bu memlekette vermiştir. Kadızade ve Ali Kuş̧̧u'nun torunları olan Kutbu'dDin Mehmed İle Mirim Çelebi Türkiye'de yüksek matematik öğrenimi ve yayınını devam ettirdiler. Osmanlı medreselerinde tıp öğretimi ilk asırlarda önemli bir yer tutuyordu. Fakat gerek matematik gerek tıp 16. Yüzyıldan sonra durdu ve daha sonraki yüzyıllarda ilkokul kitaplarından ibaret kaldı. ${ }^{33}$

Ancak 18. Yüzyıl sonlarına doğru Batı kültürünün matematik ve fizik gibi ilimlerde gösterdiği büyük ilerlemeler fark edilmeye başlandı. İlk defa Gelenbevî İsmail, eski matematik ile Batı matematiği arasında geçit vazifesi gören eserler yazdı. Fakat Gelenbevî henüz Batı matematiğine tam nüfuz etmiş sayllmazdı. Ancak $1795^{\prime}$ de kurulan Mühendishane'nin başhocası Tamanlı Hüseyin Rıfkı Efendi ile modern matematik öğretimi başladı. ${ }^{34}$

\footnotetext{
${ }^{28}$ Porphyrios, isagoji, s. 11

"Ulken. Hilmi Ziya. Tükiye'de Çağdas Düşünce Tarihi, s. 46

30 Ülken, Hilmi Ziya, "Tanzimattan Sonra Manuk Hareketleri", s. 46

${ }^{31}$ Korlaelçi, Murtaza, Pozitivizmin Türkive'ye Girisi ve Ilk Etkileri, s.178

32 Ülken, Hilmi Ziya, Türkiye'de Cuğgdaş Düşünce Tarihi, s. 46

${ }^{33}$ Ülken. Hilmi Ziya, Türkiye'de Cağdas Düsünce Tarihi, s. 44

4 Ülken, Hilmi Ziya, A. g. e. s. 25; Korlaelçî, Murtaza, A. g. e., s. 196
} 
Daha sonra Tamanh Hüseyin'in oğlu Emin Paşa bu faaliyete devam etti. Cambridge Üniversitesi'nde matematik ve fizik tahsil etmiş olan bu zat memleketimizde modern matematiği yaymaya çalışanlar arasında önemli bir yer tutar. Bu zat yüksek matematik konusunda yayımlarından çok orta öğretim için kitapları ve askeri öğretimdeki reformu ile tanınır. ${ }^{35}$

Modern matematiğe dair en esash öğretim ve yayınlar İshak Hoca (ö. 1836) tarafından gerçekleştirilmiştir. Modern matematik Tanzimattan sonra başlıca Vidinli Tevfik Paşa ile daha geniş ölçüde gelişme imkanını bulmuştu. Fakat bir asır süren bu yeni matematik yayınlarından çoğu her şeyden önce öğretici bir karakter taşımaktadır. Avrupada eğitim görmüş ve oldukça derinleşmiş bilim adamları dahi memleketin bu pratik-didaktik ihtiyacına cevap vermeye çalışırken asıl araştırma alanını ihmal etme durumunda kalmışlardır. ${ }^{36}$

Yeniçağda modern matematik çalışmalarının yeni mantık araştırmalarını teşvik ettiği gibi Türk düşünce hayatında da modern matematik araştırmalarının Türk fikir adamlarını modern mantık çalışmalarına yönelttiğini gözlemliyoruz.

Tanzimatın ilk döneminde geleneksel mantığın hakim olduğunu belirtmiştik. Bu dönemde eskiye bağlı bir bilim ve mantık anlayışının takip edildiğini görüyoruz.

"Eski tarz mantık ve ilim anlayışı asırlar boyunca işlendiği için müesseseleşmiş adetâ kalıplaşmış, bütün fikir hayatında müşterek bir anane halini almıştır. Bu durum konunun işlenmesini kolaylaştırmı̧ ve bir grup içinde ifadesini mümkün kılmıştır". ${ }^{37}$

Şimdi eski mantık anlayışına bağlı olarak yazılmış eserlerden başlıcalarını zikredecek olursak, bu devirde Ebheri (öl.1263)'nin İsagoji ve Gelenbevi'nin Mizanu'l-Burhan adlı kitaplarının şerh ve tercümeleri; telif olarak da Mehmet Hilmi, Türkçe Hülasatu'l-Mantık, Ahmed Hamdi, Manttk, Kilisli Hocazade Mehmet Tahir, Zübdetü'l-Muhtelidât min etTasdikât, Ahmet Cevdet Paaşa (1822-1895), Miyar-ı Sedat, Sırrı, Miyaru'lMakal, Abdurrahman Naim, Mantık Hülasası, Mehmet Tevfik, Gayetü'lBeyan fi Ilmi'l-Mizan, Mehmet Nuri, Ikmalu Burhan fi Tercümanı Mizan, Ahmet Hıfz1, Kısmu Tasavvurat min Hülasati'l-Mizan, Ömer Fevzi, Miyaru'l-Ulum, Ali İrfan, Methal-ı Mantık, Raşid, Mizanu'l-Makal, Said Paşa, Hülasa-i Mantık, İsmetullah, Hülasa-i Illmi Mantık adlı eserleri zikredebiliriz.

$\mathrm{Bu}$ eserlerde pedagojik gayeler ön planda tutularak, medrese ve mekteplerde okutulmak üzere yazılmış ders kitaplarıdır. Bu eserlerin hemen hepsi Ebheri'nin Isagoji adlı kitabının planı esas alınarak yazılmıştır. Bunun da esasını Stoacıların tesiriyle, İbn Sina'da mükemmel şeklini alan Aristo mantığı teşkil eder. Bu kitaplarda, metafizik konulardan uzak kalınarak daha

\footnotetext{
${ }^{35}$ Ülken, Hilmi Ziya, A. g. e. , s. 25

${ }^{36}$ Ülken, Hilmi Ziya, A. g. c. , s. 26

${ }^{37}$ Öner, Necati, Tanzimattan Sonra Türkiye'de Ilim ve Mantık Anlayışı, s. 50
} 
çok mantık'ın tekniği ele alınmıştır. Bu kitaplarda konuların ağırlık merkezini kıyas oluşturur. Tanım, önerme araştırmaları ise kıyasın hazırlık safhasıdır. İspat şekilleri ise kıyasın bir nevi tatbik yeridir. Ancak bu kısma çok az yer verilir. ${ }^{38}$

Tanzimattan sonra eğitim ve öğretim sahasında yapılan ıslahatlar neticesinde, yeni açılan okullarda medreselerden farklı bir zihniyet içerisinde eğitim ve öğretim faaliyetleri devam etmekte ve müspet bilimlere daha çok önem verilmekteydi. Bunun sonucunda batı kültürünün tesiri altında eskisinden farklı bir bilim ve mantık anlayışı gelişmeye başlamıştır. Yeni tarzda yazılan mantık kitaplarını, memlekette yapılan ilmî faaliyetlerin zorlaması neticesi, yani ilmî bir faaliyetin doğurduğu bir ihtiyacın karşıllı̆ı olarak kaleme alınmış olduğunu zannetmemek lazımdır. Bunlar da sırf Batı fikir âleminde olup bitenlerden haberdar olmak amaciyla bu alandaki yeni çalışmaların Batıdan nakledilmesinden ibarettir. Bu nedenle Yeni mantık cereyanlarında çeşitlilik hakimdir. Çeşitler arasında fikir zincirlemesi pek yoktur. Bu konuda eser veren müellifler, Avrupa'daki çeşitli cereyanları Türk fikir âlemine tanıtmaya çabalamışlardır. ${ }^{39}$

Eski ilim ve mantık anlayışı yeni gelişen bilimsel zihniyet karşısında eski etkisini kaybetmeye başlayınca bir uzlaşma çabasına girişildi. Eski mantık mücadelesine devam edebilmek için yeni bilimsel zihniyetten yararlanma yoluna gitti. Artık mantıkçılar batı fikirlerine ilgisiz kalamıyordu. Bu nedenle esasını suri (formel) mantık teşkil etmek üzere Batı felsefesinin bazı yeniliklerini içeren mantık kitapları yazılmaya başlandı. ${ }^{40}$

Eskiyle yeninin uzlaştırılması sahasında sayabileceğimiz eserler arasında Gallupi'den Miftahu'l-Fünun adlı tercüme bir eserle Ali Sedat'in Mizanu'l-Ukul Fi'l-Manttk ve'l-Usul ve Lisanu'l-Mizan adlı mantık kitaplar1 başta gelir. Türkiye'ye mantık konusunda yeni fikirler ilk defa bu kitaplarla girmiştir. Gerek Miftahu'l-Fünun mütercimi ve gerekse Ali Sedat mantık anlayışında eskiye bağlı olmakla beraber, eski mantıkçılardan farklı olarak batıdaki yeni fikirlere eserlerinde yer vermişlerdir. Bu eserlerde eski ile yeni bir araya getirilmiş, bir nevi uzlaştırıcı bir yol takibedilmiştir. ${ }^{41}$

İtalyan mantıkçısı Gallupi'den tercüme edilen Miftahu'l-Fünun adlı mantık eserini Hilmi Ziya Ülken doğrudan doğruya yeni mantık çalışmaları arasında zikrederken ${ }^{42}$ Necati Öner, Gallupi'nin izah ettiği mantığın esasını yine Aristo mantığı olması ve mantık konularının eski tarz mantık kitaplarında olduğu gibi ele alınmış olmasından ve escrlerde eskiyle yeni bir

\footnotetext{
${ }^{38}$ Öner, Necati, A. g. e. , ss. 17,47

${ }^{39}$ Öner, Necati, A. g. c., ss. 49,50

4n Ülken, Hilmi Ziya, "Tanzimattan Sonra Fikir Hareketleri", s. 15: Ulken, "Türkiyc'de Tanzimattan Sonraki Mantık Harcketleri”, s. 41

"Öncr, Necati, Tanzimattan Sonra Türkiye'de Ilim ve Mantık Anlayış, s. 50

${ }^{42}$ Bkz. Ülken, Hilmi Ziya, "Tanzimattan Sonra Fikir Hareketleri", s. 15; Ülken,

"Türkiye'de Tanzimattan Sonraki Mantık Hareketleri", s. 42
} 
arada zikredilmesinden dolayı, uzlaşmacı bir tavırla hazırlanmış eserler arasında zikretmiştir. ${ }^{43}$

Miftahu'l-Fünun yalnız bir tercüme değildir. Mütercimi esere bazı ilaveler yaptığı gibi kitabın sonuna bir de ek yapmıştır. Bu bakımdan eserin aslı Gallupi'nin olmakla beraber mütercimin mantık anlayışına göre yeni bir şekil almıştır. Bu eserle fikir hayatımıza giren yenilik, kitabın yazılışında takip olunan metotla son kismina eklenen metot konusudur. Gallupi'nin kitabında klasik tarzdan farklı olarak başka bir tarz takip edilmiştir. Eski mantık kitaplarında sentezci bir yol takip edilmiştir; Gallupi'nin eserinde ise analiz metodu kabul edilmiştir. $\mathrm{O}$, kitabına kıyas konusundan başlıyor, sonra kıyasın parçaları olan önerme ve terime geçiyor. Gallupi'nin eserinde o zamana kadar fikir hayatımızda yeni olan bir diğer nokta eserin sonunda metoda dair kısa bir konunun bulunuşudur. Burada en genel şekliyle metot konusu ele alınmıştır. Bu tarihten itibaren Türkiye'de yazılan yeni mantık kitaplarında metot konusu işlenir olmuştur. Asıl eserin kendisinden çok mütercimin, eserin sonuna eklediği "Lahika" (ek), düşünce hayatımız için yeni fikirler içermektedir. Eserin aslında olmayan tasavvurat çeşitleri, tasdik türlerine göre önerme çeşitleri ve kıyas şekilleri eski mantık kitaplarındaki gibi işlenmiştir. Daha sonra çeşitli akılyürütme şekillerinin özel kuralları diye bilimlerde metottan, son bölüm olarak da yanlış'tan bahsedilmiştir. ${ }^{44}$

Hilmi Ziya Ülken'e göre, Türk düşüncesinde, eski mantıkla yeni mantığı uzlaştırma çabası içinde olanlardan biri de İsmail Hakkı İzmirli'dir. ${ }^{45}$ Öner'e göre ise o yeni tarzda mantık konularını işlemiştir. İsmail Hakkı İzmirli, meseleleri Batılı tarzda ele almıştır. ${ }^{46}$ İzmir'li Miyaru'l-Ulum adlı kitabında meseleleri geleneğe bağlı olarak eski anlayış içinde ele almıştır. Önce bilginin kısımları olan tasavvur ve tasdikten bahseder. Sonra geleneğe uyarak mantığın önemi, konusu ve amacını açıklar. İzmirli mantık konularının Aristo'da 8 baba ayrıldığını, daha sonra Porphyrios'un İsagoji'sinin ilavesiyle 9'a çıktığını söyleyerek, mantık konularını açıklar. ${ }^{47}$ "Felsefe Dersleri" adlı eseri eski anlayış̧an farklı Batı kaynaklarından istifade ederek yazmıştır. Bazı konularda İslâm mantıkçılarının fikrine de temas etmiş, Batı mantıkçılarımın fikirleriyle karşılaştırmıştır. Eserin tümü göz önüne alınınca İzmirli'nin, bu eseri ile eski anlayışı terkettiği ve Batı mantıkçılarının mantık meselelerini ele alış tarzlarını benimsemiş olduğu görülür. Burada İzmirli'nin kendine has yeni bir fikri yoktur. Fikirlerini daha çok Paul Janet, Rabier, Boirac gibi Batılı mantıkçılardan almıştır. Bu nedenle eseri, sistematik bir biçimde ele alınmamıştır. İzmirli bu eserini "Miyaru'l-Ulum'dan tamamen farklı bir tarzda ele almıştır. Eseri iki ana bölüme ayırmış gözüküyor. Birinci bölüm kısa tutulmuş ve bilgi teorisi, fsefe ve bilimsel bilgi incelenmiştir. İkinci

\footnotetext{
${ }^{43}$ Öner, Necati, A. g. c., s. $51-54$

${ }^{44}$ Daha fazla bilgi için bkz. Miftahu'l- Fünun, İstanbul, 1928, ss. 160-189

${ }^{45}$ Ülken, Hilmi Žiya, "Türkiye'de Tanzimattan Sonraki Mantık Hareketleri", s. 42

${ }^{4 h}$ Öner, Necati, A. g. c., s. 63

17 İmirli, İsmail H., Miyaru'l-Ulum, İst. 1315, S. 5-10
} 
bölüm tamamen mantık konusuna ayrılmıştır. İkinci bölüm de kendi içinde bab'lar ve fasıl'lara ayrılmıştır. Önce formel (suri) mantık batılı tarzda ele alınır ancak konuların sırası geleneksel işleniş tarzı sırasını takip etmiştir. Mesela birinci olarak tasavvurat ele alınır ve tümeller konusu ve on kategori işlenir. İkinci olarak tasdikat, 3. Olarak akıl yürütme ele alınır sonuna da cebirsel matematikle ilgili bir lahika ekler ${ }^{48}$.

Önergeye göre, İzmirli'nin Felsefe Dersleri adhı eserinin asıl önemli olan kısmı eserin sonunda bulunan ektir. Burada Batı'da Rönesanstan sonra Aristo mantığında yapılmak istenen yeniliklere temas edilmiştir. Ancak İzmirli'nin bu konuda anlattıkları bizde yeni değildir. Daha önce Ali Sedat (1857-1900) tarafından ele alınmıştır. Fakat bu iki mantıkçımızın meseleleri ele alış tarzları farklıdır. İzmirli, Hamilton'un yüklemin niceliği meselesini izah edip bunun münakaşasını yapıyor. Boole (1815-1864)'un matematik mantığı " na kısaca temas ederek kıyasa Descartes ve Stuart Mill (18061873 )'in yapmış olduğu itirazları ve bunlara verilen cevapları naklediyor ${ }^{49}$

Öner'e göre, Izmirli, Descartes ve Mill'in klasik mantıkla ilgili itirazlarını kabul etmiyorsa da tamamen haksız olduklarını da kabul ediyor değildir. Bu nedenle gerek bu tutumu, gerekse yüklemin niceliği meselesi ve matematik mantık hakkındaki fikirleri, geleneksel mantıkta, Batıda yapılmak istenen yenilikleri, Ali Sedat gibi küçük görmez. Hatta açıkça söylemiyorsa da meseleleri ifade ediş tarzı, kendisinin bu yeni hareketlere taraftar oldugu kanaatini veriyor..$^{50}$

Uzlaşmacı bir tavırla eser veren en önemli Türk mantıkçısı da Ali Sedat'tır. Ali Sedat'ın mantık çalışmaları Türk mantık hareketleri arasında bir dönüm noktasını oluşturmaktadır. Onun fikir hayatımızdaki önemi, Batı'da Rönesans'tan sonra mantık alanında ortaya çıkan yeni fikirleri de içine alan bir mantık kitabını ilk defa yazmış olmasından kaynaklanır. Gerçi bilimlerde metot konusunu ondan önce Miftahu'l-Fünun adlı kitapta görüyoruz. Fakat Ali Sedat, formel mantıktan hiçbir yeni fikir ihtiva etmeyen bu kitabı geçerek, metot konusunu daha etraflı bir şekilde izah ettiği gibi, İngiliz mantıkçılarının Aristo mantı̆̆ı̆ üzerine ileri sürdükleri yeni fikirleri ele alıp onların münakaşasını yapmış ve devri için Avrupa'da yeni olan Boole'un matematik mantığına da ayrı bir bölüm ayırmıştır. Eserinde

${ }^{48}$ Daha geniş bilgi için, İzmirli, İsmail H., Felsefe Dersleri, Hukuk-Mat., İst. 1330; Krş. Öner, Necati, A.g.e., S. 63

... George Boole, scmbolik dili düşünce tahlilinin aleti saydığı için matematiği örnek alarak mantı̆̆ı yeniden kurmağa yönelmiştir. Bu nedenle cebirin işlem ve işaretlerini mantığa tatbik etmiştir. Bir başka ifadeyle matematiği mantığa bir nevi temel yapmak istemiştir. Boole, düşüncenin kurallarıyla matematik işlemlerin kurallarının benzerliğinden hareket ederek matematik mantığı kurmuştur. Bu yüzden o ,cebirsel mantığın asıl kurucusu olarak kabul cdilmektedir. Boole. Aristo'nun kıyas teorisinin formlarını gerçekten sembolik olarak ifade ettiğini doğrulmaktadır. Ancak bu sembolleri çok sınırlı gördüğünden matematiğin işlem ve işaretlerinin daha mükemmel olduğunu ileri sürmüş ve mantığa tatbik etmiştir.

${ }^{49}$ Oner, Necati, Tanzimattan Sonra Türkiye'de Jlim ve Manuk Anlayısı, s. 65-66

sio Öner, Necati, A. g.e., s. 67 
çeşitli cereyanlara yer vermiş olmasına rağmen bir nakilci durumunda değildir. Kendi mantık anlayışına göre bunları değerlendirmiştir. ${ }^{51}$

Ali Sedat'ın eserlerinde eski ile yeni daha çok uzlaştırılmaya çalışılmıştır. Klasik mantık konularından farklı olarak yüklemin niceliği ${ }^{* *}$ meselesiyle tümevarım hakkında Avrupa'da ileri sürülen yeni fikirleri belirterek bunların münakaşası yapılmıştır. Ali Sedat'ın kitabının en önemli yanı lahika (eki) dır. Burada (o dönemde) mantığın geçirdiği gelişmelerden, Boole ve Stanley Jevons (1835-1882)'un yeni mantık araştırmalarından, matematikle mantığın birleşmesi yolundaki çabalardan bahsedilir. Ali Sedat bu kitabında formel mantıkla tatbiki mantığı uzlaştırmak istemektedir. ${ }^{52}$

Ali Sedat, matematik mantığın bir taraftarı olarak mantık problemlerini ele almış değildir. Onun amacı memleketimiz için bilinmeyen fakat Batı fikir dünyasında tanınan bir mantık cereyanından fikir hayatımızı haberdar etmektir $^{53}$ Boole'un açtığı çı̆̆ırda yürüyen XIX. Asır mantıkçıları daha genel olan mantığı ondan daha az genel olan matematikle izaha kalkışmışlardı. Ali Sedat bunun çıkar bir yol olmadığını sezdiği içindir ki, matematik mantığa taraftar olmamıştır. Batı'da daha sonra yapılan mantık çalışmaları Ali Sedat'ı haklı çıkararak Russell ile gelişen yeni bir mantık çı̆̆ırı XIX. Asrın bu dar yolunu terketmiş; mantık çalışmaları Boole'dan farklı bir yolda gelişme göstermiştir..$^{54}$

Necati Öner, Ali Sedat'ın matematik mantığa taraftar olmadığını söylerken Hilmi Ziya Ülken bunun aksine onun klasik mantığa karşı matematik mantığı savunduğunu iddia etmektedir. ${ }^{55}$

Bilindiği gibi mantığın muhtevasız, yalnız formdan ibaret olduğu fikri yenidir. XX. Asrın başından beri gelişmekte olan yeni mantık cereyanlarının hareket noktası hep aynı fikirdir. Her ne kadar Ali Sedat eskiye bağlı mantık anlayışının tesirinde kalsa da mantığın metafizikten ayrılması gerektiği düşüncesiyle modern bir görüş sergilemiştir. ${ }^{56}$ Ali Sedat, zamanında yaşayan bir çok mütefekkirimiz, Batı'da gelişen fikir hayatından habersizken, devrinin Batı fikir hayatını tanıyıp en yeni fikirlerden memleketimizi haberdar etmek gibi önemli bir işi başarmış, bu suretle Tanzimattan sonra mantık disiplininde ilk hamleyi yaparak bu konuda öncülük etmiştir. ${ }^{57}$

\footnotetext{
5. Öner, Necati, A. g. e., s. 54

Klasik Mantıkçılar önermenin niceliğinden daima önermenin konusunun niceliğini anlamışlar, yüklemin niceliğine önem vermemişlerdir. İslâm mantıkçıları da yüklemin niccliğınin belirtildiği önermeleri "Kazaya-i Münharife” (kural dışı önermcler) olarak telakki ctmişler ve işlem dışı bırakmışlardır. Klasik mantıkta önemsenmeyip işlenmeyen bu konu XIX. Asır Ingiliz mantıkçılarınca ele alındı. George Bentham'in öncülüğü ile Hamilton yüklemin niceliği problemini işleyip geliştirmiştir. (Bkz. Necati Öner, Klasik Mannk, s. 52)

52 Daha fazla bilgi için bakınız. Ali Scdat, Mizanu'l-Ukul fi'l-Mantık ve'l-Usul, Karabat Matb.. Istanbul. 1303. ss. 204 vd;

${ }_{54}$ Öner, Necati, "Türkiyc'de Ycni Mantık Cereyanlarının İlk Habercisi Ali Scdat", s. 66

${ }_{54}$ Oner, Necati, A. g. e., s. 73

${ }^{55}$ Ülken. Hilmi Ziya, "Türkiye'de Tanzimattan Sonraki Mantık Hareketleri", s. 42

56 Öner, Necati, "Türkiye'de yeni Manttk Cercyanlannın Ilk Habercisi Ali Sedat", s. 63

57 Oner, Necati, Tanzimattan Sonra Türkiye'de Ilim ve Mantık Anlayış, s. 73; Öner,

"Türkiye'de yeni Mantık Cercyanlanının tik Habercisi Ali Sedat", s. 69
} 
Önce geleneksel eskiye bağlı mantık anlayışını, sonra Batıda ortaya çıkan yeni fikirlere de yer veren uzlaşmacı zihniyetin ürünü mantık çalışmalarını, daha sonra da doğrudan doğruya yeni mantık çalışmalarını görüyoruz.

Ali Sedat'tan sonra yazılan mantık kitapları yeni bir zihniyet içinde ele alınmış, Avrupa'da mevcut çeşitli mantık cereyanları tesirlerini Türkiye'de de göstermiştir. Yeni tarzda yazılan mantık kitaplarında Aristo mantığına az yer verilir olmuştur. Yeniçağ felsefesinde bazı yeni metafizik mantıklar da meydana çıkmış, gerek bu mantıklar gerekse Boole'la başlayan matematik mantık ve bunun gelişmesinden doğan lojistik memleketimizde tanıtılmış ve bunlar taraftar bulmuştur..$^{58}$

Yeni tarzda yazılan mantık kitapları da Batıda bu konuda yapılan yayınlar örnek alınarak eskiden farklı bir zihniyet içinde kaleme alınmış ders kitaplarıdır. Bunlar arasında liseler için M. Fazıl'ın $I l m-i$ Mantık, Ağaoğlu Tezer'in Suri ve Tatbiki Manttk, Hasan Ali Yücel'in Mantık, Hatemi Senih Sarp'ın Mantik; Üniversite için Ahmet Naim'in Ilim-i Mantık (Rabier'den tercüme), Hilmi Ziya Ülken'in Mantık Tarihi ve Von Aster'in Bilgi Teorisi ve Mantık adlı kitaplar yayınlanmıştır. ${ }^{59}$

1935-1948 y1llarında İstanbul Üniversitesinde hocalık yapan Alman Felsefe Tarihçisi Von Aster, mantığı memleketimizde yeni bir tarzda işlemiştir. Von Aster'in Bilgi Teorisi ve Mantık adlı kitabında mantık problemleri bilgi teorisi içinde incelenir. Aslen mantıkçı olmayan Aster'in Kant (1724-1801) geleneğine uyarak mantığı bilgi teorisi içinde kabul etmesi, mantığın ayrı bir bilgi kolu olmadığ ${ }_{1}$ kanaatinden kaynaklanmaktadır. Von Aster'in tanıttığı çığırı ondan sonra Türkiye'de takip eden olmamıştır. ${ }^{60}$

Avrupada Rönesanstan sonra mantık sahasında beliren yeni fikirler, Aristo'ya yapılan itirazlar, metot meseleleri, Boole'la başlayan matematik mantıktan ibaret değildir. Lojistik hakkında ilk bilgiler memleketimize Salih Zeki (1864-1921)'nin Henri Poincare'den yaptığ tercümelerle girmeye başlamıştır. Bunlar dışında kalan mantığa ait bir çok yeni fikirler, Hilmi Ziya Ülken'in Mantık Tarihi ile memleketimizde tanıtılmıştır. Ülken bu kitabında metafizik mantıklarını, Leibniz, Kant ve Hegel (1770-1831) mantıklarını tanitmaktadir. ${ }^{61}$

Leibniz bir taraftan Aristo mantı̆̆ üzerinde çalışmalar yaparken, diğer taraftan da yeni bir mantık sistemi denemelerine girişmiştir. Bir mantıkçı olarak Leibniz'in bizde tanıtılması Prof. Hilmi Ziya Ülken'in Mantık Tarihi adlı kitabı ile başlamış daha sonra Prof. Nusret Hızır, Leibniz'in yeni bir

\footnotetext{
${ }^{58}$ Öner, Necati, Tanzimattan Sonra Türkive'de Ilim ve, Mantık Anlayışı, s. 62

${ }^{59}$ A. g.e., s. 62

(N) A. g. e..s. 67

${ }^{61}$ A. g. e., s. 68
} 
mantık sistemi kurma denemelerini, Prof. Eralp yine Leibniz'in Aristo mantığı üzerinde yaptığı çalışmalarını izah etmişlerdir. ${ }^{62}$

Leibniz'e göre kavram mevcut olanın alameti değil mümkün olanın alametidir. Onun mümkün ile reel arasında yapmıs olduğu ayrım mantığın Aristo realizminden kurtulmasına sebep olmuştur. Leibniz mümkünün ne olduğunu tayin etmeye ve reel tanımlarla adsal tanımları ayırmağa çalışır. Leibniz'in tanım teorisi onda "art combinatorie" denen mantık usulünü doğurmuştur. Bu da Leibniz'de cebri sembolizmi meydana getirmiştir. İşte sembolik veya matematik mantık buradan doğmuştur. ${ }^{63}$

Ülken, Kant'ın tanım teorisi ve onun mantıkta psikolojik prensipler olduğunu iddia eden mantıkçllara karşı almış olduğu tavır üzerinde durup, Kant mantığının karakteristik vasfını belirtmeye çalışır. Kant'a göre mantık düşüncenin zaruri kanunlarının apriori ilmidir. Mantık, aklın iyi kullanılmasına ait bir ilim olup yoksa subjektif bakımdan yani psikolojik prensiplere göre kullanılmasına ait bir ilim değildir. ${ }^{6.4}$

Hegel'in diyalektik mantığı ve bu mantığın sol Hegelciler tarafından kullanılışı Mantık Tarihi adlı kitapta etraflıca izah edilmiştir. Hegel'e göre "Klasik Mantık" bir şeyin aynı zamanda hem var hem yok olamayacağı kanaatindedir. Bu hüküm ancak hareketsiz alem için doğrudur. Halbuki varlık sürekli bir oluş içerisindedir, o halde Klasik Mantığın prensipleriyle varlık arasında bir uyuşmazhlk vardır. ${ }^{65}$

Hegel bu fikirden hareket ederek diyalektik mantığ 1 kuruyor. Ülken, Hegel mantığının ve bunun sol Hegelciler tarafından yapılan tatbikatının yanlışlı̆̆ını Tarihi Maddeciliğe Reddiye ve Felsefeye Giriş adlı eserlerinde gösteriyor. Hegel mantığının ne zihnimize, ne eşyaya tatbik edilebildiğini, mantığın yapısının değişmesine imkan olmadığını izah ediyor. ${ }^{66}$ Ülken'e göre Hegel'in mantık teşebbüsü çok fazla cüretlidir. Klasik mantığı lüzumsuz bırakmak ve gerçeğin akışına uygun bir mantık kurmak iddiası ile ortaya atılan bu fikir gerçekte hiçbir ilmin gelişmesi tarafından teyid edilmemiştir. Hiçbir keşif, hiçbir icat hatta hiçbir isbat diyalektik mantığa göre cereyan etmiyor. Araştırma yollarımız (müşahede, tecrübe, deney) ve tümevarım, diyalektik mantıkla tamamen alakasız olarak işlemektedir. Bu yeni mantık teşebbüsü ancak Hegel'in kendi metafizik görüşünü meşrulaştırmak için kullandığı özel bir düşünce aleti olarak kalmaktadır. ${ }^{67^{3}}$

${ }^{02}$ Hızır, Nusret, "Yeni Mantığın Öncüsü Lcibniz", s. 433-440; Eralp, Vehbi. Matematik, Fizik ve Kimyada Metod, s. 21; Krs. Öner. Necati, Klasik Mantik, s. 91 Oner, Necati, Tanzimattan Sonra Türkive'de lim ve Mantik Anlayısı, s. 70

${ }^{63}$ Ülken. Mantı Tarihi, s. 142

is Ülken, A. g. e., s. 151

os Ülken, A. g. e., s. 215 vd; Ülken, Felsefeye Giris, (Birinci Kısım) 2.bsk, Ankara, 1963. ss. 125-127; Daha fazla bilgi için bkz. Hegel, Felsefi Bilgiler Ansiklopedisi (Mantık Bilimi), çev. Aziz Yardımlı, Idea yay., İstanbul, 1991, ss. 125 vd.; Ayrıca 172-173. Sayfalar

${ }^{66}$ Öner, Necati, Tanzimattan Sonra Türkiye' de Ilim ve Mantık Anlayışı, s. 69; krş. Ülken, Hilmi Ziya, Mantık Tarihi. s. 216; Ulken. Felsefeye Giris, s.110

${ }^{67}$ Ülken, Hilmi Ziya, Felsefeye Giris, s. 111 
Metafizik mantıklar arasında mantığı ideal bir varlık ilmi olarak kabul eden anlayış ta memleketimizde tanınmaya başlamıştır. 1952'de Takiyettin Mengüşoğlu tarafından dilimize çevrilen Heinz Heimsoeth'un Felsefenin Temel Disiplinleri adlı eserinde, ideal varlık incelenirken şunları söylemektedir: "matematiğin, mantığın, ya da pratik aklın ve genellikle değerlerin bilgisinin sözünü ettiği şeyler, yani sayılar, şekiller, yargı ve çıkarım şekilleri, ahlak yasaları ve değerler, herhangi bir şekilde vardırlar. ${ }^{\text {"*i }}$ Bu durumda matematik ve mantıksal bilginin objeleri, ya da ahlaki akıl bilgisinin objeleri ideal var olan objelerdir, Heimsoeth'e göre. ${ }^{69}$ Nicolai Hartmann tarafından ileri sürülen ve başka bir yönden mantığın diğer bilgi kollarından müstakil olarak ele alınmasını mümkün kılan bu anlayışı, Ülken etraflıca tanıtmıştır. Hartmann mantığı eski mantık anlayışı gibi ne bir alet ne de lojistik gibi totolojik sayıyor. Ona göre mantık ideal varlık bilimidir. Mantık sahası ideal bir manada kendi başına varlık sahasıdır. Mantıki hasılalar saf objelerdir ve ideal bir varlığa sahiptirler. Kavram, zihnin yaptığı bir birleşme fonksiyonu değil benzerlerinin birliğidir. İstidlal (akılyürütme) bir düşünme metodu değil genel unsurlarla tikel unsurlar arasında bulunan tabilik münasebetinin ideal halidir. Mantık kanunları ne düşüncenin ne de bilginin kanunlarıdır. Bu ideal varlığı ve ona ait münasebetleri düzenleyen kanunlardır. Bu duruma göre mantık sahası, ideal manada müstakil bir varlık sahası olarak kabul edilmiştir. ${ }^{70}$

Yeni mantık çalışmalarından sembolik mantık çalışmaları diğer mantık cereyanlarından farklılık gösterir. Diğer cereyanlar daha çok orta öğretim için yazılmış ders kitaplarında yer almıştır. Bu kitaplarda sembolik mantıktan hiç bahsedilmez. Sembolik mantık bizde ya üniversitelerde verilen dersler münasebetiyle veya öğretim gayesi ile değil de, yine üniversite hocaları tarafından şahsi çalı̧̧malar olarak ele alınmıştır. Sembolik mantık çalışmalarının tam bir savunucusu olarak Salih Zeki'yi görüyoruz. O, 1916'da neşrettiği Mizan-ı Tefekkür adlı eserinde matematik mantığı hem savunmuş hem de bütün yönleriyle açıklamıştır.

Sembolik mantık çalışmalarından matematik mantık dışında lojistik ile ilgili eserler gerek tercüme gerekse telif olarak daha fazla bir yekün tutar. Salih Zeki'nin Henri Poincare'den tercüme ettiği ve 1928'de yayınladığı Ilim ve Usul, Prof. Kerim Erim'in 1930-1932 yılları arasında Mühendis Mektebi Mecmusı'nda matematiğin esasına dair yayınladığı makaleleri ile Nazari Hesap adlı eseri, 1935'de Nusret Şükrü (Hızır)'nün Reichenbach'tan tercüme ettiği Íhtimaliyet Hesabının Mantıki Temelleri ve Dil ve TarihCoğrafya Fakültesi Dergisinde 1945-1956 yılları arasında neşrettiği makaleler, Macit Şükrü (Gökberk)'nün Carnap'tan tercüme ettiği Eski Mantık Yeni Mantık, Hilmi Ziya Ülken'in 1936'da yayınladığı Yirminci Asır

\footnotetext{
${ }^{o s}$ Heimsoeth, Heinz, Felsefenin Temel Disiplinleri, Çev.Takiyettin Mengüşoğlu, Rem7. Kit., İstanbul. 1986, s. 87

${ }^{64}$ Bkz. Heimsoeth, Heinz, A. g. e., s. 91

77" Öner, Necati, Tanzimattan 'Sonra Türkiye'de Illim ve Mantık Anlayışı, s. 70; krş. Ülken, Hilmi Ziya. Felsefeye Giris. s. 113
} 
Filozofları, Vehbi Eralp'in 1939'da Reichenbach'tan tercüme ettiği Lojistik, Ülken'in 1942'de yayınlanan Manttk Tarihi ve A. Reymond'dan tercüme ettiği Lojistik Prensipleri ve Muasır Tenkit. Hamdi Ragıp Atademir tarafından 1948'de tercüme edilip teksir halinde yayınlanan, J. L. Destouches'un Sorbonne da 1943'de verdiği derslerin ikinci kısmı, Lojistik ile ilgili Türkiye'de neşredilen çalışmalardır. ${ }^{\text {II }}$

Lojistik üzerinde Avrupada yapılan çalışmalardan fikir hayatımız, ilk defa Salih Zeki'nin Henri Poincare'den yaptığı tercümeyle haberdar olmuştur. Poincare'nin bu eserinde Russell ve Hilbert'in mantıkları ele alınıp, lojistiğin o zamanki durumu tenkit edilmiştir. Bu suretle lojistik'e ait ilk bilgiler bize tenkidiyle beraber girmiştir. Poincare'nin Ílim ve Usul adlı kitabının Türkiye'de neşrinden üç sene sonra, Prof. Kerim Erim yeni mantığı ele alarak daha ziyade bu mantığın doğuş sebebi üzerinde durmuştur. Prof. Erim matematiğin esasına dair seri halinde yayınladığı makalelerin, üçüncü, dördüncü ve altıncısında ve Nazari Hesap'ın birinci ekinde matematikte antinomiler meselesinden bahisle; cümleler kuramının tatbikinde bir takım antinomilerle karşılaşıldı̆̆ını açıklayıp, Russell, Burol Forti ve Richard'a izafe edilen antinomileri zikrediyor. Bu antinomilerin matematikte değil, klasik mantığın sonsuz cümlelere tatbikinden ileri geldiğini söylüyor. Öner'e göre, Erim, klasik mantığın yetersizliğine kanaat getirip, yeni bir mantığın gerektiği fikrini savunan lojistikçiler tarafına yönelmiştir. ${ }^{72}$

Lojistiğin daha etraflı bir şekilde tanıtılması Macit Şükrü'nün Carnap'tan yaptığ $\breve{1}_{1}$ tercüme ile olmuştur. Bu yeni mantık Reichenbach tarafından İstanbul Üniversitesinde verilen derslerle düşünce hayatımıza girmiştir. $1939 \mathrm{da}$ Reichenbach'ın ders notları Prof. Vehbi Eralp tarafından Türkçe'ye çevrilerek Logistik adı altında yayınlandı. Bu eserde iki hakikat değerli mantık ele alınır. Çok hakikat değerli mantıklara yer verilmez. Bizde yeni mantık anlayışı ile ele alınıp yazılan bu ilk mantık eserinde şu bölümler vardır: Önermeler hesabı, tahlil usulü, cümlelerin bünyesi, kelimelerin tasnifi, fonksiyonlar hesabı, sınıflar hesabı, klasik mantık, tümevarım, paradokslar, sonsuzluk kavramı ve aksiyomatik sistemler. Lojistiğin esas meseleleri olan önermeler hesabı, fonksiyonlar hesabı ve sinıflar hesabı işlemleriyle birlikte izah edilmiştir. Lojistikte asıl olan fonksiyonlar ve sınıflar hesabıdır. Önermeler hesabı bu ikisine giriş mahiyetindedir. Yüklem mantığı olan klasik mantıktan lojistiğin ayrıldığı noktalardan birisi lojistiğin münasebetler mantığı olmasıdır. Reichenbach bu iki mantık anlayıșı arasında şu iki farka işaret eder: Birincisi klasik mantığın bütün münasebetleri işlemeyişidir. Klasik mantığın kullandığı önermeler tek değişkenli fonksiyonlarla ifade edilir. Çünkü bu mantıkta birden fazla değişkenli fonksiyonlara yer yoktur. Bunlar da tek değişkenli fonksiyonlara irca edilir. Mesela "Mehmet Ali'den Büyüktür" önermesinden, eski mantıkta, formel olarak "Ali Mehmetten Küçüktür" önermesini çıkaramayız. Halbuki bir

\footnotetext{
${ }^{71}$ A.g. e., s. 80

${ }^{72}$ A. g. e., ss. $80-81$
} 
münasebetler mantığ $\breve{g}_{1}$ olan lojistikte bu ifade mümkündür. Çünkü lojistikte ikiden fazla değişkenli fonksiyonlarla da işlem yapılabilir; farkın ikincisi bir sınıfa mensup olmak münasebetiyle, bir sınıfın tali sınıfı olmak münasebeti birbirine karıştırılır. Mesela "Insanlar Ölümlüdür" önermesi gibi "Sokrat Ölümlüdür" önermesi de tümel olumlu sayılmıştır. Her iki önerme klasik mantıkta "S a P" sembolik ifadesiyle gösterilir; lojistikte ise birinci önerme "S $\Sigma$ P", ikinci önerme " $\mathrm{S} \supset \mathrm{P}$ " ifadesiyle gösterilir. ${ }^{73}$

Prof. Nusret Hızır'ın mantık tarihimizde önemli bir yeri vardır. Yeni mantık, modern mantık, sembolik mantık veya lojistik denen mantığın Türkiye'de ilk temsilcisidir. ${ }^{74}$ Prof. Nusret Hızır ikiden fazla hakikat değerli mantıkların temel kavramları hakkında neşrettiği yazısında üç hakikat değerli mantıkların temellerinin sağlam olmadığını isbata çalışıp, olasılık mantığına taraftar görülmektedir. Olasılık mantığından, Nusret Hızır'ın Reichenbach'tan tercüme ettiği Íhtimaliyat Mefhumunun Mantıki Esaslart adlı makalenin 1935 de neşrinden sonra fikir hayatımız haberdardır. ${ }^{75} \mathrm{H}$ ızır'a göre ikiden fazla hakikat değerli bir mantık sisteminin sağlam olabilmesi için o mantığın olasılık mantığı olması gerekmektedir. Hızır'ın isbata çalıştığı ikiden fazla hakikat değerli mantığın tutarsız oluşunu, makalenin neşredildiği tarihe kadar olan mantıklar için anlamak lazımdır. 1945 den sonra tutarlı olan ikiden fazla hakikat değerli mantıklar kurulmuştur. ${ }^{76}$

Prof. Ülken olasılık mantı̆̆ hakkında bir eser yazmışsa da (o dönemde) henüz neşredilmemiştir. Prof. Öner tarafından bizzat görülen bu eserde lojistiğin kısa bir tarihçesinden sonra ihtimaliyat (olasılık) mantığı etraflıca anlatılmaktadır. Ülken 1936 da neşrettiği Yirminci Asır Filozofları'ında olasılık mantığını tenkit eder. Ona göre ihtimaliyat mantığının doğru olduğunu iddia etmek, yine zımni olarak doğru ve yanlı̧ şeklindeki çift kıymetli bir mantığı kabul etmeye bağlıdır. ${ }^{77}$

Mantık cereyanlarından matematik mantık, sembolik mantık, metafizik mantık, çok değerli mantık yanında metodoloji konusu da üzerinde önemle durulan mantıkla ilgili bir alan olarak kabul edilmiştir. Bu görüşe göre, mantık bir metot bilimidir.

Aristo mantığı, eski anlayı̧̧ içinde bilimin metodudur. Aristo, mantığı fizik ve metafiziği izah için metot olarak kullanıyordu. Aristo mantığı, batı ve doğu ortaçağında bir alet telakki edilmiş ve bütün bilimsel faaliyetler için yeter metot olarak rağbet görmüştür. Rönesanstan sonra yeni bir gelişme istikameti alan bilim için Aristo mantı̆̆ı, metodoloji olarak yeterli olmayınca

${ }^{73}$ Öner, Necati. Tanzimattan Sonra Türkiye'de Ilim ve Mantık Anlayışı, s. 81-82; Öncr, Necati. "Türkiye'de Mantık Çalıs̆maları", Felsefe Dünyası, say. 6, Aralık, 1992, s. 9; Aynt tenkitler için bkz. Bertrand Russell, Diş Dünya Üerine Bilgimiz, çev. Vehbi Hacıkadiroğlu, îstanbul, 1996, ss. 47-48; Carnap, Rudolf, Eski Mantık Yeni Manytık, Felsefe Yıllığı, Bozkurt Mat., İstanbul, 1934-35, ss. 250-251; Hızır, Nusret. Felsefe Ya7ıları (Eski Mantık-Yeni Mantık), 2. Bsk., Istanbul, 1981. s. 226

74 Oner, Necati, "Profesör Nusret Hizır", Doğu Batı, yıl 3, sayı: 12, Ağustos, Eylül, Ekim 2000 . s. 70

75 Öner, Necati, A. g.e. , s. 82

${ }^{76}$ A. g. e., s. 83; Öner, Necati, "Profesör Nusret Hızır", ss. $71-72$

${ }^{77}$ A. g.e., s. 82 
yeni yollar arandı. Bacon ve Descartes'in, Aristo mantığının esasını teşkil eden kıyasa itirazları bu sebeptendir. Bacon ile başlayan yeni mantık çalışmalarının sebebini, mantığın kendi içinde bir gelişmesi olarak değil de, bilimsel faaliyetlerin zorlaması ve bu faaliyetlerin gerektiği ihtiyacı karşılamak için eski mantığı tamamlama gayretinde aramak doğru olur. O halde diyebiliriz ki, her bilim anlayışı bir metodolojiyi gerektirir. XVI. Asırdan itibaren yeni bir istikamet alan bilimde keşif ve isbat metotları için gösterilen faaliyetler, Bacon ve Descartes ile başlayan bu sahadaki yeni fikirler, bilimlerin gerek müşterek gerek tek tek metotlarının tesbitine yol açtı. Bu metodolojik fikirler Port-Royal mantıkçıları tarafından mantığa bir bölüm olarak ilave edildi. Mantık kitaplarında bu bölüm kah metot kah tatbiki mantık kah özel mantık diye adlandırıldı. ${ }^{78}$

Hamdi Ragıp Atademir Metot Üzerine adlı eserinde mantığın suri ve tatbiki diye ayrılmasını uygun bulmuyor. Sonuç çıkarmanın suri mantığın, tümevarımın ise tatbiki mantığın konusu olarak incelenmesini tamamiyle tutarsız görüyor. ${ }^{79}$

Öner de aynı fikre katıldığını beyan ederek şunları söylüyor: "Biz de mantığın suri ve tatbiki diye ikiye ayrılışı fikrinin doğru olmadığı kanaatini taşıyanlar tarafındayız. Bize öyle geliyor ki, tatbiki mantık denen bölümde işlenen fikirler esasını Aristo'nun koyduğu suri mantığın açıklanmasıdır. Öncüllerin doğru olarak tesbiti için ortaya konan birtakım yeni kaidelerdir. Zihin hangi alanda çalışırsa çalışsın, yeni bir fikir elde etmek için kullandığı yol sonuç çıkarma (tümdengelim) ve tümevarımdır. Mantık, bu işleyiş tarzının tesbitinden ibarettir. Aristo mantığı birinciye, Bacon ile başlayan yeni mantık ise ikinciye fazla önem vermiştir. ${ }^{80}$

Öner'e göre Yeniçağda bilimlerin metotları üzerindeki çalışmalar suri (formel) mantığın ayıklanmasıdır. Bu faaliyetler Aristo mantığının kötü kullanılmasının önüne geçmiştir. Öner, bilimlerin ilerlemesinde büyük rol oynayan metodoloji çalışmalarını yeni bir mantık olarak değil mevcut mantığın ıslahı olarak kabul etmektedir. Bu nedenle mantık bilimini, suri ve tatbiki diye ikiye ayırmanın mantıklı olmadığını ileri sürmektedir. ${ }^{81}$ Öner'e göre mantık bir metodolojiden çok bir varlık bilimidir. ${ }^{82} \mathrm{Bu}$ nedenle metodoloji bir mantık olamaz; hatta İslam mantıkçılarının kabul ettiği gibi bir fen bir sanat ta olamaz; mantık formel bir sistem olmanın da ötesinde ideal bir varlık bilimidir, diyebiliriz.

Batıdaki fikri çalışmalara uyarak bizde ilk defa Miftahu'l-Fünunla bilimlerde metot konusu yeni tarzda yazılan mantık kitaplarında yer almıştır. İsmail Hakkı İzmirli'nin Felsefe Dersleri adlı eseriyle mantık; genel, özel

\footnotetext{
${ }^{78}$ Öner, Necati, A. g. e., s. 85

${ }^{79}$ A. g. e., s. 85

${ }^{80}$ A. g. c., s. 85

${ }^{81}$ Bkz. A.g.e., s. 86

${ }^{22}$ Öner, Necati, "Türkiye'de Mantık Çalısmaları", s. 5; krş. Kılıc, Recep, "Prof. Dr Necati Öner İle Düşüncelerinin Gelişim Seyri Uzerine Yapılan Mülakat", A.Ü.I.F.Dergisi (Necati Öner Özel Saytst), cilt. XL, Ankara, 1999, s. 9
} 
veya suri ve tatbiki diye ikiye ayrılmağa başlanmış, bilimlerde metot konusu ikinci kısımda mütalaa edilmiştir. Bizde metot üzerine fikirler, yeni tarzda yazılmış bütün mantık kitaplarının bir bölümü olarak ele alındığı gibi bu sahada müstakil olarak da telif ve tercüme edilmiş eserler vardır. Evvelce adları geçen yeni tarzda yazılmış mantık kitaplarından başka bu konu ile ilgili olarak neşredilmiş eserler şunlardır: Telifler: İsmail Hakkı İzmirli'nin Fenni Menahic (1913), Z. Fahri Findıkoğlu'nun Metodoloji (1945), Vehbi Eralp'ın Matematik Fizik ve Kimyada Metot (1947) adlı eserlerdir. Tercümeler: Descartes'tan Metot Hakkında Nutuk (Ibrahim Etem tercümesi1895, M. Karasan tercümesi 1947), Aklın İdaresi İçin Kurallar ( M. Karasan Tercümesi, 1945), Alexi Bertrand'dan Mebadi-i Felsefe-i IIlmiye ve Ahlakiye (Salih Zeki terc. 1917), Claud Bernard (1813-1878)'dan Tipta Tecrübe Usulünün Tetkikine Giriş (Galip Ataç terc. 1934), Henri le Chaterlier'den Tecrübe Ilimlerinde Metot (Avni Yakoğlu terc. 1955) adlı eserlerdir. ${ }^{83}$

Mantığın bir konusu olarak ilimlerde metot denilince matematik, astronomi, fizik, kimya, biyoloji, psikoloji, tarih ve sosyolojinin metotları kasdedilir ve incelenir. Bilimlerde metot konusunda önce bütün bilimlerde kullanılan genel metottan sonra her bilimin kendine has olan metodundan bahsedilir. Metot konusunu bizde ilk defa ele alan Miftahu'l-Fünun ve Mizanu'l-Ukul da böyle ikili bir ayırma yoktur. Miftahu'l-Fünun'un tercüme kısmında metot olarak yalnız tahlil ve terkip incelenir. Mütercim tarafından yapılan ilavede ise tecrübe metodu izah edilir. Mizanu'l- Ukul'da doğrudan doğruya bilimler ele alınır ve her bilimin özel metotları incelenir. Daha sonra yazılan mantık kitaplarında önce genel metot izah edilip sonra bilimler ayrı ayrı ele alınarak onların özel metotlarının incelenmesine geçilir. $^{84}$

Mantığın tatbiki mantık denen bölümü bilimlerin metotlarına ayrılmıştır. Bilhassa liseler için yazılmış kitaplarda tatbiki mantığa o kadar fazla önem verilmiştir ki, suri mantığa adeta tarihi malumat kabilinden kısaca dokunulmuştur. Bu bölümde bilimlerin metotlan izah edilirken, bilimlerin konuları, gelişmeleri, ilkeleri uzun uzadıya ele alınır; gerçek mantık problemleri ikinci planda bırakılarak bir nevi bilim felsefesi yapılır. Bu tarz kitapların ikinci bir özelliği de suri (formel) mantık denen kısımla tatbiki mantık denen kısım arasında bir bağ tesisi düşünülmemiş, birbirinden ayrı iki saha imiş gibi yan yana getirilmiştir. Yalnız şunu da zikretmek lazımdır: Batı mantık kitaplarında da durum böyledir. Zaten bizde yazılan mantık kitaplarının örnekleri tamamen Batı'dan alınmıştır. ${ }^{85}$

Yeniçă̆ felsefesinde, mantığın menşei meselesi üzerinde de farklı anlayışlar doğmuştur. Bir tarafta metafizik mantıkçılarının, mantıki düşüncenin a priori bir takım esaslara dayandığı bu nedenle bu düşüncede tekamülün sözkonusu olamayacağı fikri; diğer tarafta da mantıki düşüncenin

\footnotetext{
${ }^{83}$ A. g. e..s. 86

s' Öner, Necati, Tanzimattan Sonra Türkiye'de Ilim ve Manık Anlayısı, ss. 90-91

85 Öner, Necati, A. g. c., s. 93-94
} 
bir tekamüle tabi olduğu, mantıki ameliyelerin ferdi veya kollektif şuura irca edilebileceği fikri vardır. Bu sonuncusundan mantığın psikolojik ve sosyolojik izah tarzları çıkar. Prof. Hilmi Ziya Ülken 1935 de Edebiyat Mecmuası'nda yayınladığı Türkiye'de Tanzimattan Sonra Mantık Hareketleri adlı makalesinde, mantığın psikolojik izah tarzına temas etmiş, daha sonra 1942 de A. Raymond'dan yaptığı Lojik Prensipleri ve Muasır Tenkit adlı tercüme ile bu cereyanın memleketimizde daha geniş bir tarzda tanıtılmasına çalışmıştır. ${ }^{86}$

Mantığın psikolojik izah tarzının Türkiyede rağbet görmemesine karşın, sosyolojik izah tarzı ilgi görmüş ve taraftar bulmuştur. Sosyolojik mektebin kurucusu Durkheim'dir. Ona göre mantık toplumsal hayattan doğmuştur. Bu fikri, kategoriler, kavramlar, sınıflama ve akıl ilkelerinin doğuşunda toplumsal hayatın oynadığı rolü belirterek ileri sürmüşıür. ${ }^{87}$

Ziya Gökalp, Milli Tetebbular Mecmuası'nda 1915 de neşrettiği Eski Türkler'de İçtimai Teşkilat adlı makalesiyle; 1925 de yayınlanan Türk Medeniyeti Tarihi adlı eserinin Eski Türklerde Mantık ve Eski Türklerde Illim bölümlerinde mantığın sosyolojik izahını yapmaktadır. Hüseyin Cahit (Yalçın)'ın Durkheim'den 1923 de yaptığı Dini Hayatın Íptidai Şekilleri adlı tercümesi; Necmettin Sadık (Sadak) ve Max Bonnafous'un müştereken 1927 de neşrettikleri İ̧̧timaiyat adlı telifleri; Halil Nimetullah (Öztürk)'ın 19271930 yılları arasında Darulfünun İlahiyat ve Edebiyat Fakülteleri Mecmualarında Levy-Brühl'den yaptığı Iptidai Zihniyet ve Aşağı Cemiyetlerde Zihin Fonksiyonlar tercümcleriyle sosyolojizm Türkiye'de etraflı bir şekilde tanıtıldı. Bu arada Halil Nimetullah'ın Darülfünun Edebiyat Fakültesi Mecmuası'nda neşrettiği Akıl Mantı̆̆ı ve Vicdan Mantı̆̆ adlı makalesinde her ne kadar mantığın menşeinin içtimai oluşunu iddia eden sosyolojizmden farklı bir yol tutarak iki ayrı mantıktan bahsedilmekte ise de Lévy Bruhl'ün tesirleri görülmektedir. ${ }^{88}$

Necmettin Sadık ve Max Bonnafous tarafindan neşredilen İçtimaiyat adlı eserde fransız sosyoloji mektebinin, mantık çerçevelerinin içtimai olduğu fikri Durkheim (1858-1917), Mauss ve Gökalp'ın fikirlerine dayanılarak izah edilmektedir. ${ }^{89}$

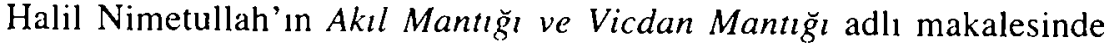
iki ayrı mantıktan bahsedilir. Bu mantık anlayışı içinde insanın bilgileri iki kaynaktan gelir: Fiziksel varhı ve toplum. Fiziksel varlığın verileri genel kavramları oluşturur. Genel kavramların terkibi ile vücuda gelen hükümler nitelik hükümleri olur ki bu mekanizmanın tümü akıl mantığıdır. Maşeri tasavvurların meydana koyduğu hükümler ise kıymet hükümleri olup bu mekanizmanın tümü de vicdan mantığıdır. Akıl mantığı çelişkiden kaçar, vicdan mantığı ise daha ziyade duygulardan oluştuğu iç̧in çelişkiye karşı

\footnotetext{
A. A. g. c.. s. $104-105$

"Öner. Necati, Fransız. Sosyoloji Okuluna Göre Mantı̆̆ı Menşei Problemi, 2.bsk., Ankara, 1977, s. 12 vd.

${ }^{88}$ Öner. Necati. Tanzimattan Sonra Türkiye'de Ilim ve Mantık Anlaysş, s. $105-106$

"Öner. Necati. A. g.e. . s. 108
} 
lakayttır. Maddi tabiata ait konuları akıl mantığı ile sosyal tabiata ait konuları da vicdan mantığı ile tetkik etmek lazımdır. Halil Nimetullah'a göre bu iki mantığın sınırı belirlenmediği için, asırlarca fikir sahasında münakaşalar olmuştur. Mesela din ile ilim kavgası bu iki mantık birbirinden ayrılırsa ortadan kalkar diyor. İlim akıl mantığını, din ise vicdan mantığını kullanır. "Fakat bu görü̧ş Mehmet Izzet tarafından tenkit edilmiştir. O, Hayat Mecmusı'nda Yamalı Ruh Yekpare Olamaz mı? adlı makalesinde, insan ruhunun biri akli diğeri vicdani faaliyet diye birbiriyle ilgisiz iki ayrı sahaya ayrılmasının doğru olmadığını belirtir. Çünkü, ona göre ruhi hayatın hedefi ruhun bütün unsurları arasında ahenk ve birlik kurup onların hepsini aynı düzene tabi tutmaktan ibarettir. ${ }^{91}$

Mantığın kaynağının açıklanmasında, Türkiye'de Fransız sosyoloji okulunun fikirleri rağbet görmüştür. Bu cereyanın taraftarlarından Ziya Gökalp ve Necmettin Sadık, mantığın kaynağının sosyolojik olduğunu açıklarken Durkheim tarafını tutmuşlardır. Halil Nimetullah'ın ise Lévy Bruhl tarafında olduğu görülür. Öner, onun vicdan mantığı dediği mantıkla Lévy -Bruhl'un açıkladığı ilkel mantığı arasında benzerlik görür. ${ }^{92}$

Türkiye'de, Tanzimattan sonra bilim ve mantık anlayışında ikilik vardır. Birincisi, Tanzimattan önceki fikir hayatımıza hakim olan İslam kültürü geleneğine bağlı anlayışın devamıdır. İkincisi XIX. Asrın ikinci yarısından itibaren başlayıp Avrupa kültürünün tesiri ile meydana gelen yeni anlayıştır. Birinci anlayış içinde daha çok dini bilgiler ön plana çıkmış mantıkta Aristo mantığının dışına çıkılmamıştır. İkinci anlayış içinde ise bilimde Auguste Comte (1798-1857)'a bağlı pozitivizm hakim olarak pozitif bilimler ön plana çıkmış; mantıkta Aristo mantığının bir metodoloji olarak yetersizliğinin anlaşılması üzerine Avrupa'da beliren, çeşitli mantık cereyanları kabul edilmiştir. Bacon'la başlayan ve mantığı bir nevi bilimler metodolojisi olarak kabul eden cereyan fazla rağbet görmüş, matematik mantık ve lojistikle, mantığın kaynağı probleminde sosyolojik izah tarzı taraftar bulmuş diğerleri yalnızca tanıtılmakla yetinilmiştir.

Eski anlayışın tek bir kapalı sistem olmasına karşılık, yeni anlayışta bir çeşitlilik vardır. Bu çeşitlilik daha çok mantık alanında görülür. Burada tek bir sistemden bahsedilemez. Aynı cereyanlar arasında da bir fikir zincirlemesi yoktur. Çalışmalar hep ferdi kalmıştır. Bizde yeni mantık cereyanları bilimsel bir zorunluluk neticesinde doğmamıştır. Halbuki, mantık bilimsel bir zorunluluk neticesinde doğar. Aristo, mantık sistemini fizik ve metafiziğini izah için kurmuştur. İslam kültüründe Aristo mantığının gelişmesi, İslamda doğan bilimlerde, tatbik sahasını bulduğu içindir. Rönesanstan sonra Avrupada beliren yeni mantık cereyanları da böyledir. Bacon'la başlayan mantık'ın yeni istikameti, tabiat bilimierindeki

\footnotetext{
${ }^{(k)}$ A. g. e. , s. 108

A. g. e., s. $108-109$

92 A. g. C., S. 109

93 A. g. e.. s. 110
} 
gelişmenin neticesidir. Lojistik ise matematikte karşılaşılan güçlükleri halletmek için doğmuştur. Metafizik mantıkları, felsefi sistemlerin izahı için, o sistemlerin zorlamasıyla meydana gelmiştir. Bu nedenle bilimsel veya felsefi bir ihtiyaç olmadan, tatbik edilecek bilimsel veya felsefi bir saha bulunmadan yeni bir mantığın doğması veya mevcut bir mantığın gelişmesi mümkün değildir. ${ }^{94}$

Yeni mantık cereyanlarına, bilimsel bir zemin mevcut olmadığı için ilaveler yapılamamışır. Ortaya atılan fikir tohumları tamamlanarak geliştirilmeyip, unutulmaya terkedilmiştir. Batı kültürüne olan hayranlığın, o kültür içinde yetişmiş Avrupalı fikir adamlarına karşı da fazlasıyla beslenmesi, kendi fikir adamlarımızın değerlerini gölgelemiştir. ${ }^{95}$

"Üniversitenin 1933 deki ıslahatı ile, 1934-1935 de, içine mantığı da alacak şekilde çok geniş bir anlamda felsefe derslerinin gayesinin tesbitinden sonra. memleketimizde klasik mantık ve metodoloji sahasında olduğu gibi, daha sonraları modern mantık sahasinda da önemli te'lif ve terceme eserler ve makaleler yayınlanmıştır",96

Bunlardan en önemlilerini şöylece sıralıyabiliriz: Sırf klasik mantık konularını ele alan eserlerden başlıcaları şunlardır: Necati Öner, Klasik Mantık, (1970), Safak Ural, Temel Mantık (1985). Bu eserlerin özellikleri klasik mantık konularında Avrupalı mantıkçıların da fikirlerine yer vermiş olmalarıdır. ${ }^{97}$

Klasik mantığın bazı kaynaklarının çevirileri de yapıimıştır. Başta bu mantığın temel kaynağı olan Aristo'nun Organon adı altındaki eserleri gelir. Hamdi Ragıp Atademir 1947-1952 yılları arasında Organon'un ilk beş kitabını çevirdi. Porphrios'un Ísagoji'si yine Atademir tarafından 1948 de; ikinci defa Isagoji Betül Çotuksöken tarafından 1986 da çevrildi. Mübahat Türker Küyel 1958-1968 arasında DTCF Dergisi ve Araştırma'da Farabi'nin mantıkla ilgili bazı eserlerinin çevirisini yayınladı. Daha sonra bu çeviriler Atatürk Kültür Merkezi Yayınları arasında ve Farabi Külliyat serisinden dört kitap halinde yayınlandı (1990).

Klasik mantığın tarihi ile ilgili bilimsel çalışmalar da yapıldı. Nihat Keklik, İslam Mantık Tarihi ve Farabi Mantı̆̆ Abdülkuddüs Bingöl, Gelenbevi'nin Mantık Anlayışı (Ankara,1978); Klasik Mantık'in Tanım Teorisi (Erzurum,1982 Doçentlik tezi); Naci Bolay, Farabi ve Ibn Sina'da Kavram Anlayışı (Erzurum 1976 Doktora Tezi, 1990 Yılında Milli Eğitim Bakanlığınca yayınlandı): Ibn Sina Mantığında Önermeler (Erzurum 1986 Doçentlik tezi): Tahir Yaren, Islam Kültüründe Mantık Çalışmalarına Karşı Fikirler, (Ankara, 1982 Basılmamış doktora tezi) ve Yine Tahir Yaren Ibn Sina Manı ğına Giriş" (Ankara-1996) adlı eserleri yazdılar.

\footnotetext{
${ }_{\text {94 }}^{94}$ Öner, Necati. Tanzimantan Sonra Türkiye' de Ilim ve Mantık Anlayışı, s. 111

9. A. g., s. 112

96. Taylan. Necip, Mantık. Tarihçesi-Problemleri, Marifet yay., İstanbul. 1981, s. 87

"Öner, Necati. "Türkiye de Mạntık Çalıı̆malari", s. 4
} 
Bu klasik mantık çalışmalarına ilaveten yine Klasik Mantık çizgisinde eserler veren İbrahim Emiroğlunun şu eserlerini zikredebiliriz: Mantık Yanlışları,İstanbul, 1993; Ana Hatlarıyla Klasik Mantık, (İstanbul, 1999)

Modern mantıkla ilgili çalışmalara gelince şunları zikredebiliriz: Reichenbach'la öğretim hayatımıza giren Yeni mantığın başlangıçta bizdeki taraftarı Nusret Hızır'dır. İstanbul'da Reichenbach'ın öğrencisi olup asistanlığını yapan Hızır daha sonra Ankara'ya gelerek Dil ve TarihCoğrafya Fakültesi'nde bu mantığın öğretimine devam etmiş̧ir. ${ }^{98}$

Nusret Hizır'dan sonra Yeni Mantıkla ilgili derslere 1961 de İstanbul Üniversitesi Edebiyat fakültesi'nde Teo Grünberg başladı. Grünberg 1966 da Ankara'ya gelerek Orta Doğu Teknik Üniversitesinde mantık derslerine devam etti. Bugün Üniversitelerimizin Felsefe Bölümlerinde modern mantık dersleri verilmektedir.".9

"Türkiyede"ki son kırk yıllık mantık çalışmalarını iki boyutta ele alabiliriz: 1. Klasik Mantık Çalışmaları: Necati Öner ve Öğrencileri. 2. Modern Mantık çalışmaları: Teo Grünberg ve Arkadaşları. Klasik mantık alanında Necati Öner'in Çalışmaları son yıllardaki klasik mantık anlayışımıza yön vermiştir."

Son otuz yılın modern mantık çalışmalarına da Teo Grünberg ve arkadaşları yön vermişlerdir. Başlangıçta Teo Grünberg ile Hüseyin Batuhan birlikte çalışmaya başlarlar. Daha sonra bunlara Cemal Yıldırım, Suvar Kösearif ve Adnan Onart katılır. Grünberg Hüseyin Batuhan, Adnan Onart ve Necati Öner ile işbirliği yaparak mantık alanında bir çok kitaplar yazdılar. Bunlardan başlıcaları şunlardır: Hüscyin Batuhan ve Teo Grünberg, Modern Mantık, 1970; T. Grünberg, H. Batuhan, Adnan Onart, Modern Mantık, 1975; Necati Öner, Teo Grünberg ve Adnan Onart, Mantık,1976; Teo Grünberg ve Adnan Onart, Mantık Terimleri Sözlüğ̈̈, 1976; T. Grünberg ve A. Onart, Manıksal Anlam Kuramı, 1980. ${ }^{101}$ Necati Öner ve Teo Grünberg çizgisi dışında mantık çalışanları ise şöylece sıralıyabiliriz: Doğan Özlem, Mantık, İstanbul, 1991; A.Ü.D.T.C. Fakültesinde Dursun Çüçen, Mantıkta Niceleyicilerin Çeşitli Yorumları Üzerine Bir Araştırma, 1978 (Doktora Tezi); Uludağ felsefe Bölümünden A. Kadir Çüçen, "Mantık" Asa yay., (İstanbul, 1999); Gazi Ü. Eğim Bilimleri Felsefe Bölümünden Zekiye Kutlusoy, Logico-Philosophical Analysis of Comparative Probability, ODTÜ, Şubat 1985 (Yüksek Lisans Tezi), Towards a Solution to the Lottery Paradox and to the Paradox of the Preface, ODTÜ, Eylül, 1994 (Doktora Tezi).

Türkiyedeki mantık çalışmalarının yeterli düzeyde olduğunu söylemek zorsa da bu konuda hatırı sayılır çalışmalar vardır. Bu gün gerek akademisyenler gerekse Üniversite dışında bağımsız araştırma yapanların

\footnotetext{
${ }^{9 *}$ A. g. m., s. 9

") A. g. m., s. 10

"100 A. Cựen, A. Kadir, "Modern Türkiye'de Mantık Çalışmaları", Felsefe Dünyası, sayı:30. $1999-2,5.47$

${ }^{101}$ Bkz. Çü̧̧en, A. Kadir, A. g. m. s. 48
} 
dikkatlerini mantık bilimine çevirdiklerini gözlemliyoruz. Türkiye'deki mantık araştırmalarının durumunu göstermek için mantıkla ilgili sayabileceğimiz incelemeleri zikretmeyi faydalı buluyoruz. Ama önce şunu da belirtelim ki, biz bu mantık çalışmalarını verirken Türkiye'deki mantıkla ilgili çalışmaların elbette bu kadar sınırlı olmadığını biliyoruz. Bununla birlikte Türkiye'deki günümüz mantık biliminin genel durumunu yansitabileceğini düşündük. Bir de bu eserleri zikretmeden önce belirtilmesi gereken bir konu da mantık bilimine bakışın değişmiş olmasıdır. Mantık cereyanları arasındaki fark, artık bu gün bir bütün mantık biliminin içinde değerlendirilmektedir. Bu gün klasik mantık, sembolik mantık, matematik mantık, modal mantık deontik mantık, epistemik mantık gibi ayrımlar mantık bilimini tamamlayan unsurlardır.

Doğan Özlem Mantık adlı kitabında şunları söylemektedir:

"Lojistikçilerin geliştirdikleri salt mantığın mantık olup olmadığı tartışılmaktadır. Lojistiği formel bir sistem saymayanlar bile vardır. Lojistik uzun süreden beri kendisini Aristoteles'in sistemleştirdiği şekliyle klasik mantığın simgeler ve matematiksel araçlarla daha zenginleştirilmiş bir devamı olarak görme noktasına gelmiştir.,"102

Daha önce İslam mantıkçıları ve Türk mantıkçıları da mantığı bir bütün olarak görmüşler; birbirine karşıymış gibi görülen farklı mantık anlayışlarını tek bir mantık bilimi içinde değerlendirmişlerdir.

Mantık tarihi sözkonusu olunca Aristoteles'ten itibaren pek çok konuda fikir ayrılıkları vardır. Antikçağ geç dönemde iki büyük mantık akımı vardır. Biri Aristoteles'e dayanan Peripatetik okul diğeri Chrysippus tarafından Megaralıların öğretilerinden geliştitilen Stoacı okuldur. Aristocu ve Stoacı okullar gerçekte birbirini tamamlasalar da o zaman alternatif teorilermiş gibi görüldü. ${ }^{103}$ Oysa Türk- İslam mantıkçıları bu farklı görüşleri aynı mantık kitaplarında ele alıp bütün farklı mantık anlayışlarını tek bir mantık bilimi içinde değerlendirdiler.

MANTIK ALANINDA YAZILAN KİTAPLAR 1998

Ahmet Cevdet Paşa, Miyar-ı Sedat, sad. Hasan Tahsin Feyizli, Ankara,

Ahmet Cevdet Paşa, Miyar-ı Sedat ve Adab-ı Sedat, sad. Necati Demir, 1998

Ankay, Aydın, Modern Mantık, Büyük Dersane Yay., Ank., 1970 İst., 1947.

Aristoteles, Organon. I Kategoryalar, Çev.: Hamdi Ragıp Atademir,

Aristoteles, Organon. II Önermeler, Çev.: Hamdi Ragıp Atademir, İst., 1947.

${ }^{102}$ Özlem, Doğan, Mantık, s. 17

${ }^{11 / 3}$ Kneale, William, Martha William, The Development of Logic, Oxford, 1962, ss. 113116 
Aristoteles, Organon. III. Birinci Analitikler, Çev.: Hamdi Ragıp Atademir, İst., 1950.

Aristoteles, Organon IV. İkinci Analitikler, Çev.: Hamdi Ragıp Atademir, İst., 1951.

Aristoteles, Organon V. Topikler, Çev.: Hamdi Ragıp Atademir, İst., 1952.

Aster, Ernst Von, Bilgi Teorisi ve Mantık, Çev.: Macit Gökberk, İÜEF Yay., İst., 1948

Atademir, Hamdi Ragıp Aristo'nun Mantık ve İlim Anlayışı, Ankara Üniversitesi Basımevi, Ankara 1974

Ayer, A. J., Dil Doğruluk ve Mantık, Çev. Vehbi Hacıkadiroğlu, Metis Yay., İstanbul, Aralık 1984 1969

Batuhan, Hüseyin, Modern Mantığa Giriş- Semiotik-Kitap 1, Ankara,

Batuhan, Hüseyin - Teo Grünberg, Modern Mantık, ODTÜ Fen- Edeb. Fak. Yay, Ank., 1970, 2. bs., ODTÜ F.E.F. Yay., Ank., 1977

Bingöl , Abdülkuddüs, Gelenbevi'nin Mantık Anlayışı, İst.- 1993

Bingöl, Abdülkuddüs, Klasik Mantık'ın Tanım Teorisi ( Aristoteles'in İbn-i Sinâ ve Port- Royal Mantıkçıları ile Sınırlandırılmış Olarak), İst.- 1993

Bolay, M. Naci, Farabi ve İbn-i Sina'da Kavram Anlayışı, İst- 1990

Budak, Zeki, Semiotik ve Dil, Modern Mantığa Giriş, Özaydın Matb., İst., 1971

Çubukçu, Aydın, Mantık ve Diyalektik, 3. Bsk., Dilek Mat., İstanbul, 1993

Durusoy, Ali, Farabi'de Bilgi Nazariyesi ve Mantık, İstanbul, 1999

Dürüşken Çiğdem, Stoa Mantığı, Ed. Fak. Yay., İstanbul, 1991

Ebheri, İsaguji, Çev: Prof. Dr. M. Sadi Çogenli- Doç. Dr. Nevzat H. Yank, Erzurum, 1999

Ebheri, İsaguji (Klasik Mantık), Çev. Rauf Pehlivan Gür, İstanbul, 1987

Emiroğlu, İbrahim, Mantık Yanlışları, M. Ü. İ. Fak. Yay., İstanbul, 1993

Grünberg, Teo - Hüseyin Batuhan, Semiotik- Genel İşaretler Bilgisine Giriş İst., 1965

Grünberg, Teo-Adnan Onart- Hüseyin Batuhan, Modern Mantık ve Uygulamaları, MEB Yay., İst., 1975; 2. bs., MEB Yay., İst., 1975; 3. bs., MEB Yay., İst., 1976

Grünberg, Teo, Epistemik Mantık Üzerine Bir Araştırma , ODTÜ FenE. Fak.Yay., Ank., 1971

Grünberg, Teo, "Temel Önermeler", Fel.Ark.s.13'den Ayrı Basım, İst., 1962

Grünberg, Teo, Anlam Kavramı Üzerine Bir Deneme, DTCF Yay., Ank., 1970

Grünberg,Teo, Sembolik Mantığa Doğru, İst., 1966

Gürtürk, Sami, Modern Mantık ve Dil, Bilim Matb., Ank., 1971

Hacıkadiroğlu, Vehbi, Kavramlar Üstüne, İstanbul, 1981 
Hızır, Nusret, "Bir Mantık Tanımı Üzerine”, DTCF Dergisi c.6, s.3'den Ayrı Basım, Ank., 1947

Hızır, Nusret, "Ernst Von Aster'in Lojistiğine Dair Bir Mektubu" DTCF Dergisi c.III, s.2'den Ayrı Basım, Ank., 1951

Hızır, Nusret, "İkiden Fazla Hakikat Değerli Mantığın Temel Kavramları Hakkında" DTCF Dergisi c.III, s.2'den Ayrı Basım, Ank., 1945

Hızır, Nusret, "Mantığın Formelleştirilmesi Üzerine Düşünceler", DTCF Dergisi c.V, S.I'den Ayrı Basım, Ank., 1947

Hızır, Nusret, "Tabiat Bilimi ve Tarih- Bir Mantık Denemesi", Atatürk Konuşmalarından Ayrı Basım., Ank., 1964

Hızır, Nusret, "Yeni Mantığın Öncüsü Leibniz", DTCF Dergisi c.III S.4'den Ayrı Basım, Ank., 1945

İnam, Ahmet, Edmund Husserl'de Mantik, Vadi yay., Ankara, 1995

Keklik, Nihat, "Farabi Mantığının Kaynakları", Şarkiyat Mecmuası IV'den Ayrı Basım., İst., 1961 1969-70

Keklik, Nihat, İslam Mantık Tarihi ve Farabi Mantığı, IUÜEF Yay, İst.,

Lachelier, Jules, Tümevarımın Temeli Hakkında, Çev.: Hamdi Ragıp Atademir, İst., 1949, MEB Yay., V+ 107 s. ; 2. bs., İst., 1967, MEB Yay., V+ 95 s.; 3. Bsk., İst., 1986.

Loringhoff, Von Freytag, Mantık. Saf Mantık Sistemi., Çev.: Tomris Mengüşoğlu, İst., 1973, IÜEF Yay., IV+ $130 \mathrm{~s}$.

Mübahat Türker Küyel, Farabi'nin Bazı Mantık Eserleri, Ankara, 1990

Mübahat Türker Küyel, Farabi'nin Peri Hermeneias Muhtasar1, Ankara, 1990

Öner, Necati, Fransız Sosyoloji Okuluna Göre Mantığın Menşei Problemi, AÜİF yay., Ank., 1965; 2. bs., AÜíF yay., Ank., 1977

Öner, Necati, Klasik Mantık, Ayyıldız Matb., Ank., 1970; 2. bs., AÜIF Yay., Ank., 1974; 3. bs., AÜİF Yay., Ank., 1978; 8. Bsk. Bilim yay., Ankara, 1988

Öner, Necati, Tanzimattan Sonra Türkiye'de İlim ve Mantık Anlayışı, AÜif Yay., Ank., 1967

Özlem, Doğan, Mantık, Ara Yay., İstanbul, Nisan 1991

Pascal, Georges, Genel Mantık ve Uygulamalı Mantık, Çev: Bilal Dindar Samsun, 1986

Porphyrıos, İsogoji, Çev.: Hamdi Ragıp Atademir, Atademir Yay., Konya, 1948, 63 s.

Porphyrios, İsagoge, Çev.: Betül Çotuksöken, Remzi Kitabevi, İst.,

Reıchenbach, Hans, Lojistik, Çev.: H. Vehbi Eralp, İst., 1939, İÜEF Yay., 95 s.

Reymond, Arnould, Lojik Prensipleri ve Muasır Tenkid, Çev.: Hilmi Ziya Ülken, Maarif Matba., İst., 1942, 207 s.

Russell, Bertrand, Mistisizm ve Mantık, Çev.: Ayseli Usluata, Varlık Yay., İst., 1972, $233 \mathrm{~s}$. 
Taylan, Necip, Mantık, Tarihçesi, Problemleri, İstanbul, 1981; 2. Bsk. M. Ü. İ. Fak. Yay.,̇stanbul,

Ural, Şafak, Temel Mantık, İstanbul, 1985

Ülken, H. Ziya, Mantık Tarihi, İ.Ü Yay., İst., 1942

Yaren, Tahir, İbn Sina Mantığına Giriş, Ankara, 1996

Yıldırım, Cemal, 100 Soruda Mantık El Kitabı, Gerçek Yaye., İst., 1976

Yıldırım, Cemal, Logic (The Study of Deductive Reasoning), 2. Bsk., Ankara, 1981)

Yücel, Hasan Ali, Mantık, Devlet Basımevi, İst., 1938

\section{Makaleler:}

"A formalization of N. Godmans Theory of Projectibilitiy", Araştırma Dergisi, c.9, ss.61-73, Ankara, 1971

"Açıklık-Doğruluk Kuramı" Abdülkadir Çüçen, 1994 Felsefe Kongresi. Bursa. 20-22 Ekim 1994.

“Akıl Yürütme Üzerine”, Fehmi Baykan, Felsefe Dünyası Dergisi, Say.

3, s.s. 55-66, Mart 1992, Ankara

"An Analysis of J. R. Searles How to Derive Ought From Is", Teo Grünberg, Araştırma Dergisi, c.7, ss. 119-127, Ankara, 1969

"Analitik Yargılar ve Apriori Yargılar", Vehbi Hacıkadiroğlu, Felsefe Tartışmaları, 15. Kitap, ss. 72-84, İstanbul, Ocak, 1994

"Anlam Sorunu" R. Levent Aysever, Felsefe Tartışmaları, 20. Kitap, ss. 70-79, İstanbul, Aralık, 1996

"Anlam Sorunun Sınırları", R. Levent Arseven, Felsefe Tartışmaları, 19. Kitap, ss.97-109, İstanbul, Nisan, 1996

"Anlam ve Yönletim Üstüne", Gottlob Frege, (çev. Şule Elkatip), Felsefe Tartışmaları, 5. Kitap, ss. 7-23, İstanbul, Mayıs, 1989

"Anlam, Doğruluk Bağlamı ve Oyunun Kuralları" Erkut Sezgin,

Felsefe Tartışmaları, 9. Kitap, ss. 24-41, İstanbul, 19

"Anlama, Belirsiżlik ve Çokanlamlılık Üzerine Bir Araştırma" Teo Grünberg, Araştırma Dergisi, c.8, ss.301-389, Ankara, 1970

"Aristoteles' in Diyalektiğinde ve Retoriğinde Tümevarım", çev. M. Kaya Sütçüoğlu, S. Knuuttila, Felsefe Tartışmaları, 24. Kitap, ss. 127-136, İstanbul, 19

"Bilimsel Düşünmede İndüksiyonun Yeri" Cemal Yıldırım, Felsefe Tartışmaları, 12. Kitap, ss.31-36, İstanbul, 19

"Bir Çıkarımda Öncüller mi Yoksa Sonuç mu Önce Gelir?", Şafak Ural, Felsefe Arkivi,

"Bir Doğruluk Fonksiyonu Mantıksal Değişmezi Olarak BağdaşmazSeçeneklilik Eklemi", Zekiye Kutlusoy, Felsefe Dünyası Dergisi, Say.31, s.s.33-47, 2000-1, Ankara

"Bir Mantık Kavramı Olarak Yanlışlık", Şafak Ural, Felsefe Dünyası Dergisi, Say.4, s.s.13-25, Temmuz 1992, Ankara 
"Bir Paradoks ve Düşündürdükleri”, Zekiye Kutlusoy, Felsefe Dünyası Dergisi.Say.15, ss.73-80,Bahar, Ankara, 1995,

"Çok-Değerli Mantık", Şafak Ural, Felsefe Arkivi S.26, 1987

"Değişkensiz Niceleme Yüklem İşlevleri Mantığı", Teo Grünberg, ODTÜ İnsan Bilimleri Derg., say.2, 1982

"Deontik Mantık ve Başlıca Sorunları", Zekiye Kutlusoy, Felsefe Dünyası Dergisi, Say.23, s.s.156-165, Kı̧̧ 1997, Ankara

"Descartesci Kuşku Deneyi ve Matematik", H. Turan, Felsefe Tartışmaları, 25. Kitap, ss.93-101, İstanbul, Temmuz, 1999

"Descartes, Moore ve Wittgenştein- Kesinlik Üzerine" Erkut Sezgin, Felsefe Tartışmaları, 17. Kitap, ss. 104-116, İstanbul, Aralık, 1994

"Descartes'in İmmanent Apriorisi" Uluğ Nutku, Felsefe Arşivi, say.20, ss.63-69, İst., 1976

"Dil, Anlam ve Felsefe", Abdulkuddüs Bingöl, Felsefe Dünyası Dergisi, Say.1, s.s.22-27 Temmuz 1991, Ankara 1991

"Diyalektik Düşünce ve Mantık", Şafak Ural, Felsefe Arkivi, S.28,

"Doğru ve Hakikat" Said Ali Ankara, Türk Yurdu, c. 3, no. 2 (296), ss. 5-7, 1961

"Doğruluğun İki Yüzü- Doğruluk ve/veya Hakikat Sorunu" Harun Tepe, Felsefe Tartışmaları, 11. Kitap, ss. 128-135, Şubat, İstanbul, 1992

"Doğruluk "Uygunluk mudur? Doğruluk Kavramları Tartışmasına Giriş: Uygunluk, Tutarlılık, Fazlalık Kuramları" Harun Tepe, Felsefe Tartışmaları, 13. Kitap, ss. 68-78, İstanbul, 19

"Doğruluğun İki Yüzü- Doğruluk ve/veya Hakikat Sorunu", Harun Tepe, Felsefe Tartışmaları, 11. Kitap, ss. 128-135, Şubat, İstanbul, 1992

"Düşünme, Dil ve Anlam", Arda Denkel, Felsefe Tartı̧̧maları, 16. Kitap, ss. 38-54, İstanbul, Ağustos, 1994

"Frege ve Aritmetik", Vehbi Hacıkadiroğlu, Felsefe Tartışmaları, 5. Kitap, ss. 65-75, İstanbul, Mayıs, 1989

"Farabi'de Düşünce ve Dil Arasindaki İlişki", Mübahat Türker Küyel, Araştırma Dergisi, c.11, ss.59-65, Ankara, 1979

"Gazâlî ve Aristoteles Mantığı," Mehmet Vural, Bilim Yolu s. 2, 1998, Kırıkkale

"Geç Wittgenstein'da Temel Önermelerin Niteliği", Aydan Turanlı, Felsefe Dünyası Dergisi, Say.14, s.s.11-17, Kış 1994, Ankara

"Heidegger Felsefesinde Doğrunun Özü Üzerine", A. Kadir Çüçen,

Felsefe Tartı̧̧maları, 17. Kitap, ss. 127-137, İstanbul, Aralık, 1994

“İbn-i Hazm'ın Mantığında Dil”, Abdulkuddüs Bingöl, Felsefe Dünyası Dergisi,Say.8, s.s.22-32, Temmuz 1993, Ankara

"Íbn Sina Mantığında Modal Önermeler ve Bu Önermelerin İbn Hazm Vasıtasıyla İslam Fıkhına Uygulanışı", Naci Bolay, Uluslararası İbn Sina Sempozyumu Bildirileri, 17-20 Ağustos, Ankara, 1983 
"İbn Sinadaki Modalitelerin Modern Mantık Açısından İncelenmesi, Naci Bolay- Teo Grünberg, Uluslararası İbn Sina Sempozyumu Bildirileri 17-20 Ağustos, Ankara, 1983

“İbn Sina’nın Mantıku'l-Meşrikiyyîn'i Üzerine Bir İnceleme”, Ali Durusoy, Yedi İklim Sanat Kültür Edebiyat Dergisi, sayr: 56, İst., 1994, ss. 56-60; say1: 57, İst., 1994, ss. 54-61, Sayı: 59, İst., 1995, ss. 57-65

"İbn Sina'nın "el- Mu'cezü's-Sağir fi'l-Mantık" adlı risalesi", Ali Durusoy, M.Ü.İ.Fak. Dergisi, yıl: 1995-1996-1997, sayı: 13-14-15, İstanbul, 1997, ss. 143-166

"Islam Mantık Külliyatının Teşekkülü”, İsmail Köz, Felsefe Dünyası Dergisi, Say. 30, s.s.91-113, 1999-2, Ankara

"İște Paradokslar!", Zekiye Kutlusoy, Bilim ve Teknik Dergisi, 330, Ankara, Mayıs 1995, ss. 18-23

"İşte Reductio", Hilmi Yavuz, Felsefe Tartışmaları, 2. Kitap, ss.131132, may1s, İst., 1988

"Kavram", Necati Öner, Felsefe Dünyası Dergisi,Say.7, s.s.2-6, Mart 1993, Ankara

"Kavramın Açıklığı ve Seçikliği", Necati Öner, Felsefe Dünyası Dergisi, Say.24, s.s.3-8, Bahar 1997, Ankara

"Kavram Kavramı", Betül Çotüksöken, Felsefe Tartışmaları, 10.

Kitap, ss.48-53, İstanbul, 19

"Kavramlar Konuları ve Gelişmeler", Harun Rizatepe, Felsefe Tartışmaları, 19. Kitap, ss. 36-43, İstanbul, Nisan, 1996

"Kavramlar ve Kendini Göstermeleri”, çev. Vehbi Hacıkadiroğlu, ,H. H. Price, Felsefe Tartışmaları, 10. Kitap, ss. 11-43, İstanbul, 19

"Kavramların Edinilmesi Üzerine Düşünceler", Harun Rızatepe, Felsefe Tartışmaları, 17. Kitap, ss. 141-150, İstanbul, Aralık, 1996

"Kavram Üzerine", Yasin Ceylan, Felsefe Dünyası Dergisi, Say.9, s.s.46-51, Ekim 1993, Ankara

"Kipler Mantığı", Dursun Çüçen, Felsefe Dünyası Dergisi,Say.26, s.s.14-24, Güz 1997, Ankara

"Klasik Mantıkta Modalite: I Modal Önermeler", Necati Öner, A.Ü.İ.Fak. Derg., c. 15, ss. 69-85, Ankara, 1967

"Kümeler Kuramı Üstüne Bazı Gözlemler", Ahmet İnam, Felsefe Dünyası Dergisi, Say.30, s.s.3-9, 1999-2, Ankara

"Leibniz'in Kiyas Teorisi", Vehbi Eralp, Felsefe Arkivi , c. 2, say. 3, ss. $65-75$, ist., 1947

"Logical Constants", Teo Grünberg, Araştırma Dergisi, c.10, ss.47-83, Ankara, 1972

"Lukasiewicz-Tarski Notasyonu", Şafak Ural, Felsefe Arkivi, Sayı 2223,1981 .

"Mantık, Matematik, Fizik Nesneler ve Felsefe". Şafak Ural, Bilim Felsefesi Seminerleri, Der: Dr. Benan Dinçtürk TÜBİTAK Marmara Araştırma Merkezi, Gebze-Kocaeli, 1997. 
"Mantığın Ana İlkeleri ve Bu İlkelerin Varlıkla İlişkileri”, Necati Öner, A.Ü.İ.Fak. Derg., c. 17, ss. 285-303, Ankara,1969

"Mantık Felsefesi Nedir?", Necati Öner, Diyanet Derg., c. 10, say.

106-107, ss. 100-103, 1971

"Mantık Felsefesi", Teo Grünberg, Felsefe Dünyası Dergisi,Say.2, s.s.8-15, Aralık 1991, Ankara

"Mantık ve Çeşitli Düşünüş Türleri", Şafak Ural, Erkenntnistheorie und Moderne Naturwissenschaften / Mantık ve Modern Doğa Bilimleri, Eds, Lucius, E., Ural, Ş., Isıs, İstanbul, 1992.

"Mantıkçı Baba-Oğul: Ahmet Cevdet, Ali Sedat, Necati Öner, Erdem, C. 2, Sayı: 6, ss.769-799, Ankara, 1987

"Mantıktaki Kıyasın Dördüncü Şekline Dair", Hüseyin Atay, A.Ü.İ.Fak. Derg., c.16, ss. 35-66, Ankara, 1968

"Mantığın Kaynağı Problemi", Abdulkadir Çüçen, Ankara İlahiyat Fakültesi Dergisi, Necati Öner Özel Sayısı,_cilt_XL, 1999, ss.83-94.

"Mantık Tarihinde Mühim Bir Hadise ve İmam Gazali", Naci Bolay, II. İslami İlimler Sempozyumu, İstanbul, Eylül 1981

"Mantıkçı Olarak İbn Kemal, Naci Bolay, Şeyhu'l-İslam İbni Kemal Sempozyumu Tebliğleri, Ankara, 1986

"Matematik Önermeleri Üzerine", Vehbi Hacıkadiroğlu, Felsefe Tartışmaları, 20. Kitap, ss. 5-19, İstanbul, Aralık, 1996

"Matematik Önermeleri", Cemal Yıldırım, Felsefe Tartışmaları, 4. Kitap, ss. 99-100, İstanbul, Eylül, 1988

"Matematik Önermeleri”, Vehbi Hacıkadiroğlu, Felsefe Tartışmaları, 3. Kitap, ss. 38-54, Eylül, İstanbul, 1988

"Matematik ve Tabiat", Said Ali Ankara, Türk Yurdu, c. 2, no. 10 (292), ss. 9-10, 1961

"Matematiksel Bilginin Neliği ve Öğeleri Üstüne", Celal A. Kanat, Felsefe Tartı̧̧maları, 21. Kitap, ss. 117-120, İstanbul, 19

"Matematiksel Kesinlik", Cemal Yıldırım, Felsefe Tartışmaları, 3. Kitap, ss. 28-37, Eylül, İstanbul, 1988

"Matematik Tüm Bilimler İçin En Uygun Dil Midir?", Ayhan Sol, Felsefe Dünyası Dergisi,Say.19, s.s.75-81, Kış 1996, Ankara

"Modalite Meselesi ve Modal Önermeler Yönünden Aristo İle Farabi’nin Bir Mukayesesi”, Naci Bolay, Seminer Dergisi (Özel Say1), İzmir, 1989

"Nerde Bu Argüman",Tunca Eşel, Felscfe Tartışmaları, 2. Kitap, İstanbul, 1988

"Nominalizm", Teo Grünberg, Araştırma Dergisi, c.6, ss.47-69, Ankara, 1968

"Olanaklı Dünyaların Varlıksal Statüsü Üstüne", Semiha Akıncı, Felsefe Tartışmaları, 25. Kitap, ss. 118-123, İstanbul, Temmuz, 1999

"Olasılık Kavramının Toplum Bilimlerdeki Yeri” Füsun Akatlı, Varlık Dergisi, Sayı: 62, 1964, ss.28-29 
"Önerme Kavramının Gelişimi", Erkut Sezgin, Felsefe Tartışmaları, 5. Kitap, ss. 76-83, İstanbul, Mayıs, 1989

"Önsel Bilgiler ve Zorunlu Önermeler", Teo Grünberg, Araştırma Dergisi, c. 12, ss. 281-286, Ankara, 1981

Petitio Principii Nedir?", İbrahim Emiroğlu, Felsefe Dünyası Dergisi, Say.9, s.s.65-75,Ekim 1993, Ankara

"Prensipler ve Bazı Mantık Prensipleri",Vehbi Eralp, Felsefe Arkivi, say. 18, ss. 1-10, İst., 1972

"Reductio Nerde?", Tunca Eşel, Felsefe Tartışmaları, 2. Kitap, ss. 133134, İstanbul, 1988

"Salih Zeki Bey' in Mantık Görüşü", Adnan Ömerustaoğlu, Akademik Araştırmalar, Yaz, 1996

"Sayının Tanımlanması", çev. Celal A. Kanat, Bertrand Russell, Felsefe Tartı̧̧maları, 21. Kitap, ss. 157-162, İstanbul, 19

"Sembolik Mantık ve Uygulaması", Şafak Ural, Felsefe Arkivi, Sayı 26, 1987

"Semerkandi'nin Kıstas'ında Kıyas Teorisi", Abdulkuddüs Bingöl, Felsefe Dünyası Dergisi, Say.20, s.s.10-34, Bahar 1996, Ankara

"Stoa Mantığı", Çiğdem Dürüşken, Felsefe Arşivi, Sayı: 281993

"Soru-Yanıt Mantığı", Uslamlama ve Ussallık, Erdal Cengiz, Felsefe Dünyası Dergisi,Say.18, s.s 56-62,Kış 1995, Ankara

"Tanzimattan Sonra Türkiye'de İlim ve Mantık Anlayışı", Necati Öner, A.Ü.İ.Fak. Derg., c. 5, ss. 100-135, Ankara,1956

"Tanzimattan Sonra Türkiye'de İlim ve Mantık Anlayışı",Necati Öner,

A.Ü.İ.Fak. Derg., c.V, ss.100-135, Ankara, 1958

"Türk Mantıkçıları", Mehmet Ali Aynî, İstanbul Daru'l-Funun İlah.

Fak. Mec., say.10, ss.49-64, İstanbul, 1928

"Türkiye'de Mantık Cereyanlarının ilk Habercisi:Ali Sedat", Necati Öner, A.Ü.i..Fak. Derg.,, c. 6, ss. 60-69, Ankara,1957

"Two Levels of Logical Competence", Nail Şahin, Araştırma Dergisi, c.12, ss. 49-281, Ankara, 1981

"Uslamlama Üzerine Yazışma”, Harun Rızatepe, Felsefe Tartışmaları, 4. Kitap, ss. 49-56, İstanbul, Eylül, 1988

"Viyana Çevresi", Nusret Hızır, Araştırma Dergisi, c.2, ss.245-257, Ankara, 1964

"Wittgenstein ve Carnap: Tractatus'un Mantıkçı Pozitivizme Etkisi”,Gürol Irzık, Felsefe Tartışmaları, 11. Kitap, ss. 59-81, Şubat, İstanbul, 1992

"Yeter Sebep İlkesi", Wilfred Stache, Felsefe Arkivi , c. 3, say.1, ss. 8184, Ist., 1952

"Yüklemin Niceliği Meselesi ve İbn Sina Mantığında Yüklemi Nicelikli Önermeler", Naci Bolay, Uluslar arası İbn Sina Sempozyumu Bildirileri, 17-20 Ağustos, Ankara, 1983" 


\section{Tezler}

Ahmet Cevdet Paşa'da Münazara Metodolojisi, Süleyman Büyüker, E. Ü., Kayseri, 1991, Y.L.T.

Aristoteles'in Retorik Kanıtlama Teorisi, M. Kaya Sütçüoğlu, Ege Ü., İzmir, 1997, Dr. T

Çok-Değerli Mantık, Cemil Güzey, İ.Ü., 1989

Doğrulama Kuramı, Şafak Ural, İ. Ü. , 1982

Ebheri'nin İsagojisi'nin İlk Şerhleri, Ahmet Kayacık, E. Ü., Kayseri, 1996, Dr.T

Ebu Nasr Farabi'de Kategoriler - Aristo İle Mukayeseli Tahlil-,Nihat Keklik, İ. Ü., İstanbul, 1955, Dr. T

Farabi ve İbn Sina'da Kavram Anlayışı, M. Naci Bolay, Atatürk Ü., Erzurum, 1976 Dr. T.

Farabi'de Kategoriler, Nihat Keklik, İ.Ü., 1955

Fransız Sosyoloji Ekolüne Göre Mantı̆̆ın Menşei Problemi, Necati Öner, A. Ü., Ankara, 19, Doç. T

Gazzâlî Felsefesinde Bilgi ve Yöntem, Mehmet Vural, Ankara Ü., Ankara, 1997. Dr. T.

Gazzali'nin Mihakkü'n-Nazar fi'l-Mantık'ı, Ahmet Kayacık, E. Ü., Kayseri, 1991, Y.L.T

Gelenbevi'nin Mantık Anlayışı, Abdülkuddüs Bingöl, A.Ü., Ankara, 1978, Dr. T.

Husserl'de Mantığın Yeri, Ahmet İnam, İ. Ü., 1974 Dr. T.

İbn Sina Mantığında Önermeler, M. Naci Bolay, Atatürk Ü., Erzurum, 1981, Doç. T.

İslam Kültüründe Mantık Çalışmalarına Karşı Fikirler, M. Tahir Yaren, A. Ü., Ankara, Dr. T T)

İslam Mantıkçılarında Modalite Teorisi, İsmail Köz, A. Ü., 2000 (Dr.

Mantık ve Hukuk Felsefesinde Kıyas, A. Ulvi Mehmedoğlu, M. Ü., 1993, Y.L.T.

Mantık Yanlışları Üzerine Bir Araştırma, İbrahim Emiroğlu, D. Ü., Izmir, 1991, Dr. T.

Necmü'd-Din Ali b. Ömer al-Kâtibî'nin Hayatı, Eserleri ve Mantıktaki Yeri, Hüseyin Çaldak, Atatürk Ü.,Erzurum, 1998, Y.L.T

Ödev Mantığı, Hamide Rencüzoğlu, A. Ü., 1993

Salih Zeki'de Mantık Matematik İlişkisi, Adnan Ömerustaoğlu, Atatürk Ü., Erzurum, 1995, Y.L.T

Salih Zeki'nin Mantık Anlayışı, İsmail Köz, A.Ü., 1992 (YI. T)

Stoa Mantığı, Çiğdem Dürüşken, İ.Ü.F.E.F., İstanbul, Dr. T

Tanzimat'tan Sonra Türkiye'de Illim ve Mantık Anlayışı, Necati Öner, A. Ü., Ankara, 1956, Dr. T 


\section{Bibliyografya}

Bayraktar, Mehmet, İslam Felsefesine Giriş, Ankara, 1997

Bingöl, Abdulkuddüs, Osmanlı Dünyasında Manttk Bilimi ve Eğitim, Felsefe Dünyası, Sayı: 29, Temmuz 1999-1, ss. 12-20

Çüçen, A. Kadir, Modern Türkiye'de Mantık Çalışmaları, Felsefe Dünyası, sayı:30, 1999-2, s.47

Eralp, Vehbi, Matematik, Fizik ve Kimyada Metod, İstanbul, 1947,

Farabi, İhsaul Ulum, Çev. Ahmet Ateş, 3. bsk., İstanbul, 1990

Hegel, Felsefi Bilgiler Ansiklopedisi I(Mantık Bilimi), Çev. Aziz Yardımlı, İdea yay., İ stanbul, 1991

Hızır, Nusret, Yeni Mantığın Öncüsü Leibniz, A.Ü.D.T.C.F. Dergisi, c. III, sayı: 4, Mayıs-Haziran, 1945

Hızır, Nusret, Felsefe Yazıları, 2. Bsk, İstanbul, 1981

İzmirli, İsmail Hakk1, Miyaru'l-Ulum, İstanbul, 1315

İzmirli, İsmail Hakk1, Felsefe Dersleri, Hukuk Mat., İstanbul 1330

Kilıç, Recep, Prof. Dr. Necati Öner İle Düsüncelerinin Gelişim Seyri Üzerine Yapılan Mülakat, Ankara Ü. İlahiyat Fakültesi Dergisi, Necati Öner Özel Sayısı, cilt XL, 1999, ss.83-94.

Kneale, William and Martha, The Development of Logic, Oxford, 1962

Korlaelçi, Murtaza, Pozitivizmin Türkiye'ye Girişi ve İlk Etkileri, İnsan yay., İstanbul, 1986

Leibniz, Metafizik Üzerine Konuşma, Çev. Nusret Hızır, M.E.B. Yay., İstanbul, 1949

Miftahu'l- Fünun. İstanbul, 1928

Öner, Necati, Profesör Nusret Hızır, Doğu Batı, yıl 3, sayı: 12, Ağustos, Eylül, Ekim 2000, (ss. 65-73)

Öner, Necati, Tanzimattan Sonra Türkiye'de İlim ve Mantık Anlayışı,

A.Ü.İ.F.Yay., Ankara, 1967

Öner, Necati, Türkiye'de Mantık Çalışmaları, Felsefe Dünyası, say. 6, Aralık, 1992, ss. 2-11

Öner, Necati, Türkiye'de Yeni Mantık Cereyanlarının İlk Habercisi: Ali Sedat, A. Ü. İ. Fak. Dergisi, C. VI, sayı: I-IV, 1959

Öner, Necati, Klasik Mantık, 6. Bsk., Ankara, 1991

Öner, Necati, Fransız Sosyoloji Okuluna Göre Mantığın Menşei Problemi, 2.bsk., Ankara, 1977

Porphyrios, İsagoji, Çev. Hamdi Ragıp Atademir, Konya, 1948

Bertrand, Russell, Dış Dünya Üzerine Bilgimiz, çev. Vehbi Hacıkadiroğlu, İstanbul, 1996,

Sedat, Ali, Mizanu'l-Ukul fi'l-Mantık ve'l-Usul, Karabat matb., İstanbul, 1303

Taylan, Necip, Mantık, Tarihçesi-Problemleri, Marifet yay., İstanbul, 1981

Ülken, Hilmi Ziya, Mantık Tarihi, İstanbul, 1942

Ülken, Hilmi Ziya, Tanzimattan Sonra Fikir Hareketleri,Tanzimat I 
Ülken, Hilmi Ziya, Türkiye'de Çăğdaş Düşünce Tarihi, 2. Bsk., İstanbul, 1979

Ülken, Hilmi Ziya, Felsefeye Giriş, (Birinci Kısım), 2.bsk., Ankara, 1963

Ülken, Hilmi Ziya, Türkiye'de Tanzimattan Sonra Manttk Hareketleri, Edebiyat Fak. Tarih Mecmuası, sayı: 1, İstanbul, Mayıs- 1934

Yaren, Tahir, İbn Sina Mantığına Giriş, Ankara, 1996 